\title{
What Determines Preferences for an Electoral System? Evidence from a Binding Referendum
}

\author{
Guillem Riambau* Steven Stillman ${ }^{\dagger}$ Geua Boe-Gibson ${ }^{\ddagger}$
}

December 12, 2019

\begin{abstract}
Much has been written about politicians' preferences for electoral systems, yet little is known about the preferences of voters. In 1993, New Zealand had a binding electoral referendum on the same day as the general election where voters chose between keeping a single plurality system (First Past the Post) or introducing a pure proportional one (Mixed Member Proportional). This paper merges data from all nationwide polling stations to Census data on local voters to examine what drives citizens' preferences for an electoral system. We find that strategic partisan interest was a key driver: voters overwhelmingly preferred the system that most benefited their favorite party. However, socioeconomic characteristics and social values also mattered; people who held more progressive values, were outside the dominant religion and lived in urban areas were much more likely to vote to change to a proportional system. Survey data show that these findings hold at the individual level, and further, that individuals who were angry with the economy were much more likely to vote against the status quo, regardless of their background, party preferences or social values. This behavior is likely to have ultimately balanced the result in favor of Mixed Member Proportional.
\end{abstract}

Keywords: Elections, Electoral Systems, Voting Behavior, Referendum, New Zealand. JEL classification: D72, D73, H11

*Universitat de Barcelona and IPERG. email: griambau@gmail.com

${ }^{\dagger}$ Free University of Bozen-Bolzano. email: Steven.Stillman@unibz.it

${ }^{\ddagger}$ University of Waikato. email: boegibson@gmail.com All supplementary materials can be found at http://guillemriambau.com/ 


\section{Introduction}

A country's electoral system is a key determinant of many of its political outcomes. How politicians are elected has been shown to matter for the degree of female representation (Duverger, 1955, Norris, 1985, Matland and Studlar, 1996), the level of redistribution (Iversen and Soskice, 2006, Persson et al., 2007), the level of corruption (Persson et al., 2003), party dynamics (Duverger, 1951; Kedar et al., 2016), public spending (MilesiFerretti et al. 2002, Lizzeri and Persico, 2001) and a wide range of policy outcomes (Morelli, 2004).1 Given the impact that this choice has on policy outcomes and hence welfare, it is critical to understand how countries end up with different electoral systems out of a wide range of possible alternatives. The existing literature on this topic has mainly focused on politicians' preferences, likely because they are the most visible actors in the process of choosing an electoral system. So far, a key actor who has been generally overlooked is the electorate. This paper aims to fill this gap.

One of the reasons citizens' preferences have likely been overlooked is the relative scarcity of past electoral system changes that included mechanisms for popular participation. Between 1961 and 2011, there were only twenty-four relatively serious attempts to change electoral systems in OECD democracies, with only nine changes being realized (Bol, 2016). In this paper, we focus on one of these serious attempts, which also happened to be a successful one: New Zealand, which, until 1993, was "a perfect example of the Westminster model of democracy" (Lijphart, 1984), with all Members of Parliament (MPs) selected from single member plurality districts and with only two parties alternating office between 1938 and 1993. Specifically, in 1993, New Zealanders faced a binary choice between keeping a long-established First Past The Post system (FPTP) or changing to a proportional system known as Mixed Member Proportional (MMP). This binding referendum had very high turnout (85 percent of the eligible electorate voted). In the end, 54 percent of voters chose MMP, which became the new electoral system in 1996, when the following general election took place.

Our main analysis uses data from all 4,273 polling stations in New Zealand, which we geocoded. We merged this data set with the Census in order to obtain the socioeconomic characteristics of voters at each polling station. Hence, we can closely examine the relationship between voting outcomes and voter characteristics. Importantly, the general election (still under FPTP) was held at the same time as the referendum. As a result, for

\footnotetext{
${ }^{1}$ See $($ Carey and Hix 2013$)$ and $($ Grofman, 2016) for a comprehensive summary.
} 
each polling station, we know the party shares and also the proportion of votes for MMP. This allows us to examine the role of partisanship as well as socioeconomic characteristics in determining citizens' preferences for an electoral system. Since the average station has only 450 voters, our analysis is undertaken at a very low level of aggregation, which means that we are able to control for a wide range of location-specific characteristics.

We also perform two additional analyses to support our main findings. First, a small subset of 150 urban polling stations had polling booths for two or even three nearby electoral districts. In these cases, the socioeconomic characteristics of the electorate in each district are nearly identical, while for historical reasons, the preferred party in these neighboring districts often differs. This allows us to estimate polling station fixed effects models that examine the relationship between past party voting patterns and referendum voting controlling for all unobservable socioeconomic characteristics. Second, we use survey data from the 1993 New Zealand Election Study (NZES) to examine the same question using individual level data. Notably, the survey contains information on party support, referendum vote, general election vote and a wide range of socioeconomic characteristics and political attitudes. This is critical since this data allows us to examine individual-level relationships while controlling for a wider range of individual preferences and opinions.

We find robust evidence that partisan preferences drove voters' choices; people supported the system that was thought to most benefit their favorite party. This is the case when examining the full cross-section of polling stations, when examining only polling stations with polling booths for more than one electorate, and when using the NZES data to examine individual voting behavior. Importantly, results using survey data are robust to controlling for socioeconomic characteristics, self-placement on a left-right ideological scale and support for different political parties. Even with these controls, the party an individual votes for strongly predicts how they voted in the referendum. Interestingly, supporters' voting patterns seem to strongly mimic party cues: National was undoubtedly in favor of the status quo, and so were their supporters. Labour, the other big party, did not send a clear message, and we likewise find ambivalence among its base core. When it comes to smaller parties, their leaders strongly encouraged change to MMP. We find that their supporters overwhelmingly voted for MMP.

However, partisan preferences do not fully explain electoral system choice. Socioeconomic characteristics and social values also matter; people who hold more progressive 
values, are more educated, are outside the dominant religion, are male, and live in urban areas were much more likely to support changing to a proportional system. Survey data confirms these findings at the individual level and, notably, also shows that individuals who were angry with the economy were much more likely to vote against the status quo, regardless of their background, party preferences or social values.

It is important to emphasize that these preferences cannot result from a distaste for malapportionment or gerrymandering, which are both non-existent in New Zealand due to an electoral law that strictly bounds the electoral commission against both, which results in electorate boundaries being completely arbitrary. It is most likely that the patterns we uncover reveal an intrinsic preference for particular democratic processes. Supporting this, we also find that individuals who put intrinsic value on characteristics usually associated with proportional systems, such as coalition governments and a fair mapping from votes to seats, are also much more likely to support MMP.

The main contribution of our paper is that, to the best of our knowledge, it is the first to use field data from a binding referendum to examine individual determinants of electoral system choice 2 The referendum we examine is particularly relevant for understanding individual preferences because all adult New Zealanders had an equal say in the outcome. There had been a non-binding referendum in the previous year on the same decision, which means that the issue of electoral system reform was extremely salient. The few studies that have previously examined individual preferences for electoral systems have mainly relied on hypothetical choices made in surveys, and on experiments by participants in contexts where an actual electoral reform was not on the agenda (Blais et al., 2015, Aldrich et al. 2014, Wenzel et al., 2000). Despite the strengths of these papers, they all have in common that respondents were answering questions regarding a relatively abstract and unlikely event. $3^{3}$ Lack of saliency has been shown to be a problem in survey-based studies, since it results in satisficing and socially desirable answers (Krosnick, 1999).

In general, our results are consistent with previous literature which also finds that voters are usually self-interested in hypothetical situations Aldrich et al. 2014; Wenzel et al. 2000) 4. In this light, our results confirm that hypothetical choice experiments

\footnotetext{
2 Nakaguma (2015) uses a similar strategy to understand preferences for the form of government, presidential versus parliamentary, using data from the 1993 Brazilian referendum.

${ }^{3}$ The only exceptions we know of are Aimer and Miller (2002) which also examines the New Zealand referendum but only uses the NZES in a descriptive manner and Fournier et al. (2011) which examines a sample of citizens who chose to be part of a long-term deliberative process (one year, $20+$ meetings). As the authors acknowledge, this has obvious self-selection issues.

${ }^{4}$ Fournier et al. (2011) is an exception but relied on self-selected participants who were all members
} 
are a reasonable way to collect information about individual's preferences for different electoral systems, and that salience does not appear to change the underlying importance of partisanship in determining people's choices. However, this paper is the first one to show that social values are also important determinants of individual preferences for electoral systems, and, in particular, that voter anger could have played a small but determinant role on the referendum outcome. 5 This type of sentiment is obviously difficult to capture in hypothetical situations and, as the evidence from the Brexit referendum and 2016 US Presidential election suggest, in pre-election polling. Taken together, our results highlight how the timing of any referendum may be a key determining factor, especially in relatively close races where economic or political dissatisfaction could sway enough votes to overturn expected results.

\section{Theoretical framework}

The literature on the origins of electoral systems has mostly focused on the role played by political elites. As a result, the analysis of preferences for electoral systems has primarily paid attention to candidates - or, more generally, parties or policymakers. Broadly speaking, two reasons have been put forth to explain why different parties prefer different electoral systems: self-interest and general-interest (Bawn, 1993; Benoit, 2004, Boix, 1999 , Bowler et al., 2006, Colomer, 2004, Norris, 2011). Self-interest preferences reflect each party's expectations about the payoffs that different electoral institutions will have either in the form of policy outcomes or perks from office. General-interest preferences refer more broadly to preferences for institutional outcomes that affect the general, rather than partisan, interest. That is, related to issues of fairness, governability or accountability, and usually related in some way to the political processes rather than outcomes for specific parties $\sqrt[6]{6}$

There is little previous research on voters' preferences for electoral systems. The exceptions have generally assumed that voters like political parties have rational preferences that align with their political goals and values. In particular, previous research has found of local assemblies in the Netherlands, Ontario and British Columbia.

${ }^{5}$ Voter anger was particular relevant at the time of this referendum because in the late 1980s New Zealand underwent a massive free-market de-regularization where campaign promises had been repeatedly broken by both major parties (Roper and Leitch, 1995)

${ }^{6}$ However rational political agents may be assumed to be, the literature also recognizes that most electoral reforms cannot simply be explained by short-term self interest motivations (see, for instance, Benoit (2004); Katz (2005); Norris (2011). 
that self-interested preferences are a key explanation for how voters rank different electoral systems. In other words, voters generally prefer systems that benefit their most preferred party (Wenzel et al., 2000; Aldrich et al., 2014, Blais et al., 2015, Weber, 2017).7 Given that both under FPTP and MMP local representatives are chosen via majoritarian rule at the district level, we posit that voters have the national level in mind (i.e., government presence or representation in parliament). In light of this, our first prediction is as follows:

Hypothesis 1. [Partisan]: Voters support the electoral system that most favors their preferred party at the national level.

Note that when it comes to casting a vote, preference for the system that most favors one's most preferred party is observationally equivalent to having no strict preference for (or knowledge about) any of the systems and basing the choice on one's preferred party's recommendation. Without information on the information available to voters, it is not possible to separate these two channels.

Alternatively, voters could rank electoral systems on self-interested preferences that go beyond strict partisan lines. According to social dominance theory, members of high status groups should support institutions that favor their group. Hence, if the political system as a whole and the electoral system, in particular, were deemed to play a role in the maintenance of social hierarchies, the optimal strategy for high socioeconomic status voters (high-SES) would be to support the status quo, whereas those with lower-SES should be voting to overturn it 8 This prediction is summarized as follows:

Hypothesis 2. [Status quo]: High-SES voters are in favor of maintaining FPTP, whereas lower-SES voters are in favor of MMP.

Individuals' own ideological self-placement in the left-right spectrum could also have consequences on their attitudes towards different electoral systems. For instance, Bowler et al. (2006) argue that right-wing voters should be "reluctant to support changes of any kind and, thus, express more affect for the current institutional arrangements" (p. 437). Blais et al. (2015) summarize a number of political psychology studies and conclude that "left-wing voters [should be] more attracted by new voting rules" (p. 428). Left-wing

\footnotetext{
${ }^{7}$ In particular, Aldrich et al. (2014) show that when voters expect a landslide victory of their favorite party, they prefer a 'winner-take-all' system, whereas when they are uncertain that their party will get the majority of votes, they prefer a proportional split. This is consistent with elites' choices as shown in Trebbi et al. (2008).

${ }^{8}$ See Sidanius et al. (1994) and all work cited therein for a discussion on hierarchy-enhancing ideologies and social dominance theory. This hypothesis is also consistent with prospect theory: in their seminal piece, Quattrone and Tversky (1988) show that in the political arena people behave similarly as when making economic decisions. I.e., risk-averse in gains and risk-seeking in losses.
} 
voters could also be more supportive of MMP because historically it has been proven that governments elected using PR on average provide higher levels of redistribution ( and Tabellini, 2004); (Iversen and Soskice, 2006)). In light of these, we make the following prediction:

Hypothesis 3. [Ideology] Voters on the right of the political spectrum will be in favor of the status quo, whereas those to the left will prefer a change.

Previous work has also tested whether voters' preferences can also be shaped by a general interest, which refers to preferences for securing a set of fair and clean political processes, such as fairness, transparency, representativity or accountability (Fournier et al. 2011; Nakaguma, 2015; Wenzel et al. 2000). That is, as the case for political elites, preferences for institutional outcomes that affect the general, rather than partisan, interest. These motives can be distinguished from the ones exposed thus far as being strictly based on selfless interest. For instance, Nakaguma (2015) rationalizes Brazilian's choice for a presidential system in 1993 as a means to reduce corruption. Wenzel et al. (2000) find that citizens who prefer more consensual decision-making processes (as opposed to strong government efficacy) are more supportive of a proportional representation system, whereas Aldrich et al. (2014) find that preferences for an electoral system are correlated with socio-economic background: in particular, the younger and more educated are more supportive of a proportional rule. Based on these, we make the following prediction:

Hypothesis 4. [Values] Voters support the electoral system they believe most favors their preferred set of political processes and rules.

Finally, a number of recent papers have identified the phenomena of protest voting, i.e., voting for a party other than one's favorite in order to signal political dissatisfaction (McAllister, 1982).9 There is no reason to believe protest voting should not exist in referenda. In fact, just to name two recent ones, voting for Brexit in 2016 or turning out to vote (for either option) in the 2017 Catalan independence poll have been regarded as 'protest votes' Goodwin and Heath, 2016, Kauffman, 2016; Lynskey, 2017; News Europe 1. 2017). This leads to our final prediction:

Hypothesis 5. [Protest] Voters who are discontent with the economic and political situation cast a vote against the status quo, regardless of their preferences.

In our scenario, this translates into voting for MMP. As discussed below, our main

\footnotetext{
${ }^{9}$ See, for instance, Hooghe and Dassonneville 2018); Kselman and Niou (2011) or Pop-Eleches (2010).
} 
analysis links polling station data to census information on local areas. This data can only be used to test the first two predictions discussed here as we do not have information on voter ideology, values or discontent. However, our secondary analysis using data from the New Zealand Election Survey is able to both confirm our main findings for the first two predictions, and test the next three predictions discussed above.

\section{New Zealand context}

\subsection{Events leading to the referendum: 1978 - 1993}

New Zealand was throughout most of the 19th century "a perfect example of the Westminster model of democracy" (Lijphart, 1984). Government was (and still is) elected by the Parliament, which is the only legislative chamber in the country. Up to and including the 1993 election, all MPs were selected from single member plurality districts. Due to an electoral law that strictly bound the electoral commission against malapportionment by mapping district size to the population in the South Island, the number of districts incremented regularly throughout the years, from 80 in the immediate post Second World War, to 99 in 1993. Conservative National and leftist Labour were the only two parties in office between 1938 and 1993, winning nearly all MPs in each election.

Both the 1978 and 1981 elections ended up with National in office even though Labour won the plurality of votes. This resulted in a Labour pledge to establish a Royal Commission of non-partisan individuals to reappraise the electoral law. The Commission's report suggested that the best possible system for New Zealand was a proportional system known as Mixed Member Proportional (MMP). Perhaps unsurprisingly, "[h]orrified politicians of both major parties (then) attempted to put the genie of reform back in the bottle" (Nagel (2004), page 534). This effort was successful until David Lange, the Labour candidate in the 1987 elections, promised a binding referendum during a TV debate if Labour won the elections. This promise has been widely regarded as a political gaffe. 10

Despite a Labour victory in 1987, the referendum was never set. Given the rising concerns about fairness and representation among large sectors of the population, the National party, in an attempt to shame Labour, promised a binding referendum in case they won the 1990 elections, to which Labour followed suit. Party elites mostly opposed

\footnotetext{
${ }^{10}$ It was "made in a context of ongoing pressure for a referendum on the electoral system, increasing public dissatisfaction with the political process and intensifying concern about the government's willingness to override public opinion" (Vowles (2008), page 24).
} 
the referendum, yet realized it was politically perilous to do so publicly (Vowles, 2008). National then won the 1990 elections and proceeded to set a two-stage process for deciding the electoral system. A first referendum, held in 1992, was non-binding; it asked citizens whether they would prefer to remove FPTP, and, if so, to choose which was the best possible alternative among four suggested.11. If voters in the first referendum supported change, there would then be a second binding referendum in 1993 asking voters to choose between FPTP and the highest ranked alternative from the first referendum.

Not surprisingly, given its non-binding nature, participation was relatively low in the 1992 referendum (55.2\%). However, an overwhelming majority voted to replace FPTP (84.7\%) and among the four candidates to replace it, MMP was the most preferred, with seven in ten voters supporting it as the best alternative. Notably, the context in New Zealand in the late 80s was of great disengagement with politics and politicians, during which both Labour and National had implemented a drastic liberalization of the economy. As former Labour Prime Minister Mike Moore stated, "[T]he people didn't speak [on referendum day]. They screamed." Levine and Roberts (1993), page 162).

The stage was now set for the binding referendum to be held at the same time as the 1993 general election. Few members of the National Party now supported change. Senior Labour politicians were giving cues to vote against MMP, whereas those closer to the voters (such as key activists and less tenured candidates) generally supported MMP (Vowles, 2008). Smaller parties, like Alliance or New Zealand First (NZF), were unambiguously supportive of MMP. In a last minute attempt to prevent MMP, a group of business leaders stepped into the breach left by demoralized politicians, by launching a lavishly funded, sophisticated advertising blitz in support of FPTP, called 'Campaign for Better Government' (Roper and Leitch, 1995). Panel B of Table 1 summarizes the vote shares and seats won by the major parties in the general election, as well as their position with regard to the referendum.

[Table 1 about here]

The 1993 referendum saw a sharp increase in participation (85.2\%) and a much closer result: MMP was preferred by $53.9 \%$ of voters (referendum official results are summarized in Panel A of Table 1). The new electoral law established MMP for the 1996 general election and required it to be used for at least two consecutive elections before any serious

\footnotetext{
${ }^{11}$ The four possible alternatives were Single Transferable Vote (STV), Supplementary Member (SM), Alternative Vote (AV) and Mixed Member Proportional (MMP).
} 
evaluation could be made. ${ }^{12}$ Overall, the process that culminated in this referendum has been described as "driven by chance" (Benoit, 2007), "serendipity" (Nagel, 2004), or even "accidental" (Vowles, 2008).

\subsection{Mixed Member Proportional: a brief summary}

The Electoral Commission proposal for MMP (which is what was implemented after the referendum) is very similar to the electoral system that prevails in Germany. The country is divided into electoral districts with the number of districts determined by total population; it was 65 in 1996, right after the implementation of MMP, and is at the time of writing this article 71, all nearly equal in population. The number of MPs, however, is fixed at 120.13 On election day, citizens cast two votes: the 'party vote' and the 'electorate vote'. All nationwide party votes are tallied together (i.e., as if one district). Vote shares from the party vote determine the share of votes that a party will get in parliament. The electoral formula chosen was Sainte-Laguë, which means that the translation from party vote shares to seat shares in parliament is nearly exact.14 The electorate vote, on the other hand only serves to decide who is the representative at the local level; here plurality rule still abides. 15

\subsection{Other relevant aspects of the New Zealand electoral system}

One peculiarity of the New Zealand system is the existence of Māori-only electorates. These special electorates were introduced in 1867 under the Māori Representation Act. As a consequence, every area in New Zealand is covered by both a General and a Māori electorate. By law, Māori citizens (around one sixth of the total population) can choose whether to register in a General district, or in a district in which only Māori can enroll (and vote). All non-Māori citizens must enroll in the General roll. From 1896 to 1993,

\footnotetext{
${ }^{12}$ A non-binding referendum was held in 2011 , in which $57 \%$ of the population voted to keep MMP.

${ }^{13}$ Unless there is an 'overhang', a situation in which the number of MPs may increase in very small numbers. Overhang situations arise when a party wins more districts than the number of MPs designated via the party vote.

${ }^{14}$ Parties are required to get greater than five percent of the overall party vote or win an electoral seat to get their full allocation of seats in parliament.

${ }^{15}$ As an example, suppose that a party wins $35 \%$ of the party votes and wins in 20 of the 71 electorates with the 'electorate vote'. Given that $35 \%$ of 120 is 42 , this party gains 42 MPs. The first 20 MPs are those who have won the local race via the electorate vote. The other 22 are the first 22 members of the nationwide party list. On the other hand, if a party wins more electorates than the MPs allocated with its share of the party vote, then a situation of an overhang arises. For example, if a party wins $6 \%$ of the party votes (which translates into $7 \mathrm{MPs}$ ) and 9 electorates, then the number of total MPs rises to 122 , and the party gets to keep all its 9 locally elected MPs.
} 
the number of Māori seats was fixed at four. Figure 1 shows all electorates in a map.

Changing to MMP had a particularly large impact for Māori. It was decided that if MMP was implemented the number of Māori seats would no longer be fixed at four. Instead, they would now depend upon the number of Māori registered in the Māori Roll (following the same population rules as the electorates in the General Roll). Importantly, this would mean that the number of Māori-only districts could dramatically increase in the long run if more Māori chose to register in the Māori Roll ("Electoral Act, 1993"). ${ }^{16}$ Currently, there are seven Māori seats ${ }^{17}$

[Figure 1 about here]

Important for the interpretation of some of our findings, New Zealand has strong rules against malapportionment. Specifically, the Electoral Amendment Law of 1945 states that the registered population in any given district could not be more or less than 500 people of the established quota, which was later modified in 1950 to deviate by at most \pm $7.5 \%$ and in 1956 by at most $\pm 5 \%$, where it has stayed ever since. ${ }^{18}$ Hence, redistricting is an uncommon phenomena driven entirely by population change. Because of the fixed number of Māori seats, Māori are the only group in New Zealand who 'lost out' under FPTP due to how the electoral map was drawn.

Another important detail relevant for implementing our empirical strategy is that while voters in New Zealand can vote in any polling station within their electorate, historically nearly all have chosen to cast their votes on election day at the closest polling station.19 While it is possible to vote in another electorate on election day if an individual is traveling, this requires a 'special' vote and is relatively costly in terms of paperwork. Hence, the sociodemographic characteristics of individuals living in the area near a polling station can be thought of as a very accurate representation of the preferences of the voters at that station.

\footnotetext{
${ }^{16}$ The "Electoral Act (1993)", reprinted as of July 1, 2017, can be found at http://www. legislation. govt.nz/act/public/1993/0087/latest/DLM307519.html.

${ }^{17}$ Labour traditionally won all of the Maori seats which may be an additional reason why many party members were supportive of changing to MMP.

${ }^{18}$ Electoral Amendment Act, 1945, Nov. 12, No. 10; Electoral Amendment Act, 1950, Oct. 6, No. 32; Electoral Amendment Act, 1956, Oct. 26, No. 107.

${ }^{19}$ According to the 'Voter and non-Voter Survey Report' issued by the Electoral Commission, 93\% voted in a polling station closest to their home in 2008, whereas $92 \%$ did so in 2011 . There is no data available for previous elections, but there is no reason to suspect that patterns have recently changed in any particular direction.
} 


\section{Data and empirical strategy}

\subsection{Data}

Our main analysis relies on data that we combined from two different datasets that cover the whole country: $(i)$ election and referendum results at the polling station level and (ii) the general Census. The general election and referendum results dataset contains information from all 4,273 polling stations, with an average of 449 votes cast in each. In order to infer the sociodemographic characteristics of voters at each polling station, we geolocate them and merge comprehensive information on individuals living in the area of the polling station from the 1996 Census.20 Since 1996, Statistics New Zealand has released comprehensive sociodemographic information at the "Area Unit" level. There are nearly 2,000 area units in New Zealand, which are generally suburbs in urban areas, small towns or district rural areas, and have on average 1,884 usual residents. Most area units $(73 \%)$ have one or at most two polling stations in them. Hence, the characteristics of individuals living in the area unit of a polling station should be quite representative of the voters at that station. ${ }^{21}$ We also use separate information at the area unit level on the proportion of Māori registered in the General Roll versus the Māori Roll ${ }^{22}$

We drop all "special vote polling stations", which include hospital votes, ordinary votes and special votes before polling day, special votes on polling day and overseas votes. ${ }^{23}$ We do so because we do not have information on the sociodemographic characteristics of these voters, which is critical to our empirical strategy. Given the potential bias in preferences among Māori driven by the "Electoral Act (1993)" (see Section 3.3 above), we also exclude polling stations from the Māori Roll. Our final analysis sample includes data from $1,637,117$ voters at 3,244 polling stations, which covers $85.4 \%$ of the total number of votes cast in the election. Table 2 shows basic information on these polling stations for the full sample and our analysis sample. There is no apparent bias in terms of party or electoral system preferences in our restricted analysis sample of polling stations. In the Supplementary Materials, we show that all our results hold when we include polling

\footnotetext{
${ }^{20}$ We are able to geolocate all but seven polling stations which we exclude from our analysis.

${ }^{21}$ The few area units that have three or more polling stations are generally large ones in rural areas. In the Supplementary Materials (Tables IV, VI and VIII) we show that when we cluster standard errors at the area unit level all results hold.

${ }^{22}$ This dataset is not publicly available and was obtained directly from the Electoral Commission. It contains data from 1998. Since the changes in roll composition were minor from 1993 to 1998, we take this as an adequate proxy for the 1993 roll composition.

${ }^{23} \mathrm{~A}$ special vote is a vote made by an elector who is unable to visit a polling place in their own electorate on election day, or is not on the electoral roll on election day.
} 
stations in Māori districts.

[Table 2 about here]

Finally, in Section 5.3, we use survey data from the 1993 New Zealand Election Study (NZES). This was a post-election survey that was administered through a self-completion questionnaire. 2,251 individuals responded (around $70 \%$ of those initially targeted). This survey included questions on referendum choice and party choice for the elections, as well as the usual battery of questions on sociodemographics, party preferences, political attitudes, social values, etc. As discussed above, we use the NZES to test whether our main results hold up when examining individual voting behavior and to examine the importance of additional characteristics that can only be captured in a survey for voting decisions.

\subsection{Empirical strategy}

Our main unit of observation is the polling station matched to the sociodemographic characteristics of voters in the Area Unit in which the station is located. Our main regression specification is as follows:

$$
\% M M P_{i}=X_{i a} \beta+\sum_{P}\left(\delta_{P} \% P_{i}+\gamma_{P} \% P_{i}^{2}\right)+\varepsilon_{i a}
$$

where $\% M M P_{i}$ is the percentage of votes for MMP in polling station $i ; X_{i a}$ is a vector of sociodemographic characteristics of Area Unit $a$ in which polling station $i$ is located; and $\% P_{i}$ is the share of votes for party $P$ in polling station $i 24$ We include the vote share in a quadratic form because, as will be shown below, there appears to be a nonlinear relationship between vote shares and voting for MMP. Because there are multiple polling stations in the same electorate, we cluster all standard errors at this level. We weight all results by number of votes at the polling station, so that our results indicate the relationship for the average voter as opposed to the average polling station.

\footnotetext{
${ }^{24}$ Table II in the Supplementary Materials shows the descriptive statistics for the sociodemographic characteristics we include in the regression.
} 


\section{Results}

\subsection{Main results}

Figure 2 shows the distribution of results at the electorate and polling station levels. There was a wide distribution of voting results in the referendum; in some polling stations less than $20 \%$ of people supported changing to MMP while in others over $80 \%$ of voters supported the change. Table 3 reports the OLS results of regressing the share of votes for MMP on sociodemographic characteristics (i.e., expression (1) above without party shares). ${ }^{25}$ Some patterns stand out: urban areas and areas with a higher proportion of residents born abroad strongly supported MMP; similarly, the higher educated and those who were more dependent on the state subsidies for income were more supportive of MMP. Māori and women seemed also more supportive of MMP, although these results are not robust to all specifications. Finally, results on the coefficients for income indicate a hump-shaped relationship between income and preferences for MMP. ${ }^{26}$

[Figure 2 about here]

[Table 3 about here]

[Figure 3 about here]

[Figure 4 about here]

[Table 4 about here]

Next, we examine the correlation between partisan support and electoral system choice. Figure 3 shows the geographical distribution of support for MMP (Panel $a$ ) and for the three biggest parties (Panels $b-d$ ). These figures suggest a strong correlation between party support and electoral system choice: whereas National strongholds were more supportive of FPTP, areas where Alliance and Labour were predominant showed a stronger support for MMP. Figure 4 further examines this by plotting the unconditional relationship between party support and support for MMP. Support for MMP linearly decreases with support for National. Similarly. the relationship between support for Labour or Alliance and support for MMP is positive. However, we should not that, after a certain

\footnotetext{
${ }^{25}$ Our preferred specification in all tables is the last column. We report different specifications to provide evidence that results are consistent throughout, and not a result of our particular choice.

${ }^{26}$ Table III in the Supplementary Materials shows that results are robust to including all polling stations from Māori electorates.
} 
threshold, support for MMP does not seem to increase, however extreme the support for either of these parties.

Table 4 reports the OLS results of regressing the share of votes for MMP on sociodemographic characteristics and party shares (i.e., expression (1) above). ${ }^{27}$ All patterns just discussed hold. When controlling for all sorts of socioeconomic characteristics, National supporters prefer FPTP, Labour strongholds show moderate support for MMP, and supporters of Alliance strongly prefer MMP. The negative sign on the squared party vote shares for Labour (column 2) and Alliance (columns 3 and 4) further supports non-linear relationship between vote shares for these parties and support for MMP that is hinted in Figure 4 .

Figure 5 shows the magnitude of these effects by plotting predicted support for MMP from results in Table 4 -i.e., controlling for all sociodemographic characteristics. All graphs use the same scale for ease of comparison of the magnitude of the effect. Two main lessons arise: first, the stronger effect is for National: for every percentage point increase in vote shares for National, there's a drop of around 0.5 percentage points in support for MMP. In comparison, the effect for Alliance, while unambiguous in favor of MMP, is much smaller: for every percentage point increase in vote shares for Alliance, there's an increase of around 0.25 percentage points in support for MMP. And, second, the results for Labur seem to perfectly mimic the ambiguity (or lack of consistency) displayed by its party leaders: the relationship is a near perfect U-shape.

[Figure 5 about here]

\subsection{Matched Polling Stations}

In New Zealand, citizens can cast their vote at any polling station within the electorate they are registered in ${ }^{28}$ Especially in urban areas, there are voters - mainly those who live at the edge of their electorate - for whom the closest polling station is located in the electorate next to the one they are registered. Historically, in order to facilitate participation and reduce the costs of voting, the electoral commission has decided to set polling booths for two electorates in the same polling station (sometimes, in some corners,

\footnotetext{
${ }^{27}$ Table V in the Supplementary Materials shows that all results hold when including Māori and votes in polling stations that are not located geographically (i.e., "special" votes).

${ }^{28}$ Technically, citizens can also cast their vote in other electorates, but this involves a serious amount of paperwork and very few voters resort to it.
} 
for even three electorates). Importantly, votes are tallied separately by electorate within those polling stations. There are approximately 150 such polling stations.

As discussed above, we focus on these stations for one of our robustness tests. Table 5 illustrates our approach with examples from three of these stations, (Forrest Hill Church Hall, K.C.E.P.B. Depot, and King George Hall). Figure I in the supplementary materials illustrates the case of a particular polling station serving both North Shore and Glenfield electorates in a map.

[Table 5 about here]

The three examples shown in Table 5 reveal that differences in results across ballot boxes within the same polling station can be striking. We use this to set a pairwise matching strategy. Given that the vast majority of citizens vote in the closest polling station, all voters in any such polling station $i$ can be safely assumed to share the same socioeconomic characteristics, regardless of the electoral district booth they effectively cast their vote in (section B in the supplementary materials confirms that this is a valid assumption). Essentially, electorates are completely arbitrary boundaries and, in urban areas, all polling booths draw from a local area since they are densely located. Hence, people who vote in the same polling booth are mainly coming from the same neighborhood, they just happen to reside in different electorates. As (Gibson et al. 2013) note, "New Zealand appears to have ample polling places per voter. Electorates in New Zealand each have an average of about 50 polling places, and at each an average of just 600 votes are cast in the 10 hours that the polls are open. (...) The average distance by road to the nearest polling place in urban areas is one kilometer (0.6 miles). This is comparable to the distances found in previous US studies. Based on this distance, the average round trip by car to the nearest polling place would take just five minutes of traveling time, while for urban areas it would take only four minutes. (pages 3 and 7 )"

As a result, differences in partisan support and electoral system choice across voting booths in the same polling station must be driven by unobservables at the electorate level, like MP quality or pork barreling. Since we have general election results for 1990 at the electorate level, we use them as a proxy for such unobservables. We cannot include any results for Alliance, since it did not run prior to the 1993 election. We however include New Labour in the regression, a small party that was founded in 1989 by former members of the Labour party. New Labour ran in 1990, winning $5 \%$ of the votes and one seat (the only party other than National and Labour to win a seat), and joined the coalition of 
parties that would run in 1993 under the name 'Alliance'.

To be precise, our identification strategy works as follows: let $M M P_{i g}^{93}$ be the share of votes for MMP in polling station $i$, electorate $g$. Also define the difference in party support in 1990 between National and Labour in electorate $g$ as $\Delta_{g}^{90}$. We run the following regression:

$$
\% M M P_{i, g}^{93}=\Delta_{g}^{90}+\delta_{i}+\varepsilon_{i}
$$

Since those who vote in polling station $i$ electoral district $g$ and those who vote in polling station $i$ electoral district $h$ are observationally equivalent in their socioeconomic characteristics, in essence, what we are doing is checking whether 1990 election results have explanatory power on 1993 referendum choices over and above socioeconomic characteristics.

[Table 6 about here]

Results from estimating equation (2) are shown in Table 6. Let us first note that, due the the smaller sample size, non-linear effects are much harder to capture, so we omit squared variables. Results further confirm party preferences as a key driver for electoral system choice - the larger the vote share for National in the previous elections, the smaller the support for MMP. The opposite relation holds for Labour and New Labour (the biggest party other than the big two in 1990), with the magnitude of the effect being twice as large for the latter. the larger the margin in favor of National in previous elections, the smaller the share for MMP in 1993. The larger the support for a small party like Alliance, the larger the vote share for MMP. Furthermore, when we add controls that proxy for 'degree of rurality' (see specification 5), results shown above are also confirmed: residents of relatively more rural electorates tend to support FPTP over and above party considerations, even when controlling for their voting location.

Figure 6 shows the magnitude of these effects by plotting predicted support for MMP from results in Table 6. In this case, vote shares for all three parties have similar magnitudes, but we can observe that confidence intervals are also much wider due to the smaller sample size.

[Figure 6 about here] 


\subsection{Results using survey data}

To further check for the robustness of results displayed thus far, we use data from the 1993 New Zealand Election Study. The original data set consists of 2,251 post-election respondents. Due to missing data issues, we can only use 1,296 subjects for our analysis. Table VII in the Supplementary materials shows the descriptive statistics: there seem to be no observable patterns for missing data. The survey contains the usual battery of questions on socioeconomic background and political attitudes. The following is our main regression specification:

$$
M M P_{i}=\alpha+X_{i} \beta+P O L_{i} \gamma+\varepsilon_{i}
$$

where $i$ refers to an individual respondent, $X_{i}$ is a vector of individual socioeconomic characteristics, and $P O L_{i}$ is a vector of political preferences, attitudes, and values. All results throughout are clustered at the electorate level. We include only those respondents who voted in the referendum.

[Table 7 about here]

Table 7 shows the results. In column (1), we show that, as with field data, there is a strong relationship between which party an individual voted for in the 1990 election and whether they support FPTP or MMP in the referendum. In particular, those who voted for Labour are more likely to support MMP relative to those that voted for National and this difference in even larger for people who voted for other parties in 1990 and for those who did not vote. These results are robust to the inclusion of controls for a widerange of characteristics. Columns (2) and (3) include further controls: first, a variable that captures how much the respondent supports the core values of MMP (shares of MPs equal to shares of votes, and coalition governments); and, second, degree of support for the main three parties contesting in 1993. All results hold.

[Table 8 about here]

[Figure 7 about here]

Furthermore, survey data allows us to assess whether partisanship and ideology act as complements or substitutes. To do so, we look at voters who support small parties (hence, who are predicted to vote in favor of MMP) that are to the right of the political spectrum (and, hence, predicted to vote against MMP): these are voters of New Zealand 
First, and Christian Heritage. ${ }^{29}$ Results are presented in Table 8; these unambiguously show that partisanship is more important than ideology for these voters. Supporters of New Zealand First were around 20 percentage points more likely to vote for MMP than National voters, whereas supporters of Christian Heritage were around 10-18 percentage points more likely 30

Examining individual characteristics, we find that, on average, men, Māori, highly educated, leftist, and middle aged people were more likely to support MMP 131 We find that, on the contrary, protestants, the main religious group in New Zealand, were more likely to support FPTP. Unfortunately, the Census does not provide religious breakdown, so we can only rely on survey data to study religion effects. The correlates of social values and electoral system support are striking. We find that holding more progressive values is clearly associated with having voted for MMP; rejecting death penalty, being in favor of employing homosexuals, and being more open to immigrants is positively correlated with having chosen MMP.

[Figure 8 about here]

Results also reveal that respondents who claimed to be 'sometimes', 'often' or 'always' angry with the economy were more likely to support MMP. Importantly, this result holds even when controlling for past vote, support for principles of MMP, and support for parties. In other words, anger at the economy was a key driver in the referendum vote all across the political spectrum. Finally, perhaps unsurprisingly, people who support the basic tenants of MMP, such as coalition governments and a fair mapping from votes to seats, were in addition much more likely to support MMP.

Figure 8 shows the magnitude of some of these effects. In particular, we include the effect of supporting Alliance (subfigure 8e) as a means of comparison. The effect of formal education and progressive values is only marginally smaller than that of supporting for a small party who could clearly benefit from MMP. The effect of anger at the economy is even larger (although it reduces to around one half when including controls for party

\footnotetext{
${ }^{29}$ Unfortunately, the 1993 NZES survey did not include respondents' perceptions of the left (0) - right (10) position of these parties, but the 1996 survey did so. On average, New Zealand First was placed at 5.4, whereas the Christian Coalition, the coalition that included Christian Heritage and the Christian Democrat Party, was placed at 6.9. For reference, National and Labour were at 6.9 and 3.7.

${ }^{30}$ We would like to note that these results hinge on a small subset of our respondents: in our sample, there are 102 voters of New Zealand First (7.9\% of the total) and 18 of Christian Heritage $(1.4 \%)$.

${ }^{31}$ Most specifications show that Māori are significantly more likely to support MMP. Nonetheless, Māori are highly underrepresented in the 1993 sample. Hence, given the small number of observations, we prefer to take this result with a grain of salt.
} 
support).

\section{Discussion}

We find consistent evidence in support of Hypothesis 1, that is, that voters rationally supported the electoral system that benefited their favorite party the most. The majority of National supporters voted to keep FPTP, whereas Alliance supporters voted for a switch to MMP, as both party elites encouraged. Remarkably, all our results are less clear with regards to Labour supporters, which is very much in line with the ambiguous behavior of its party elites. Whereas, on average, Labour supporters were more favorable towards MMP, Labour strongholds did not vote for MMP as much as National strongholds did for FPTP, as Figure 5 clearly shows. In terms of effect size, controlling for all possible individual characteristics, survey data reveals that voting for Labour increased the probability of voting for MMP only half as much as voting for Alliance - see Figure 7 .

Expectations about voting patterns may have been particularly salient among National voters: since the Second World War, Labour and National had typically gathered $80 \%$ of the popular vote and virtually all seats in all elections. National had secured government in 11 out of the 16 general elections, whereas Labour won the other five. Up to 1993, most, if not all, smaller parties were left-leaning. In the eyes of many National supporters, this meant that, should voting patterns stay the same after the referendum, the introduction of a proportional system would probably result in Labour and smaller leftist parties easily gaining the majority of parliamentary seats in every election. This is likely to have led a vote for FTPT (i.e., status quo) among most instrumental National supporters.

Our hypotheses 2-5 reflect that there are potentially many other factors that drove people's choices over and above party allegiances. In particular, Hypothesis 2 implies that socioeconomic status should influence choices. This is confirmed by the data. Three socioeconomic characteristics are strong predictors: formal education, residence, and religion. We find that residing in urban areas and having higher levels of formal education are strongly correlated with support for a proportional system. Results on formal education are remarkable; once controlling for party preferences, vote at the general election, and all sorts of social values and political attitudes, having any degree higher than a primary school degree increases the probability of supporting a pure proportional system by around 10-15\%. This suggests that those with higher levels of formal education place 
some intrinsic value in a proportional system beyond the instrumental partisan value they may see in it. Given the lack of malapportionment, support of urban citizens for MMP is unlikely to stem from an urge to increase the weight of their own individual votes. Hence, support of 'urbanites' and 'leftists' for MMP seems more likely to derive from the tendency of these subsets of the population to antagonize National. It is also plausible that highly educated, urban citizens, who have generally stronger concerns for the environment, may have supported a proportional system in the hope of facilitating entrance to parliament to the Green Party.

We also find religion to be a driver of electoral preferences. Followers of the main religion in New Zealand (Protestantism) were much more supportive of maintaining FPTP than their Catholic or agnostic counterparts. As far as we know, there is nothing intrinsic in the Protestant set of beliefs that would favor a majoritarian system. As part of the majoritarian religious group, Protestants may have seen little need to alter the status quo.

Results for income are mixed when using field data. On the one hand, median income in the area unit is positively correlated with supporting FPTP. However, on the other, larger proportions of lower-income households are also correlated with more support for FPTP, whereas larger proportions of people earning rents and dividends is associated with stronger support for MMP. Survey data does not shed any further light on the issue. In sum, support for Hypothesis 2 is mixed at best, and, if anything, evidence leans towards rejection: whereas those in urban areas and highly educated seem to vote against status quo, those in the majoritarian religion group tend to vote in favor. Results on income do not yield further clarifications.

Hypothesis 3 seems to find more support in the data: those who placed themselves to the left of the political spectrum tended to support a proportional system. This result is however not robust to all specifications. In particular, we find that partisanship trumps ideology, as supporters of small right-wing parties overwhelmingly tended to support MMP. Hypothesis 4 states that values and preferences for political processes are determinants of referendum choice. Results show that, indeed, values and attitudes have an impact on electoral preferences over and above party preferences and socioeconomic characteristics. We use respondents attitudes towards immigration, the death penalty and homosexuals to measure values. We find that being more progressive made respondents more likely to support a proportional system. The effects are not trivial; someone who strongly supports progressive values was around 10 to 25 percentage points more likely 
to support MMP than someone who strongly supports conservative values (depending on the specification).

There are two reasons why less conservative individuals could be more supportive of a proportional system: (a) by principle, should they believe that a proportional system is intrinsically more valuable than a majoritarian one; or (b) instrumental, should they believe it is more conducive to bringing about progressive political outcomes. Unfortunately, given our data, we cannot disentangle the actual effect of each of these rationales. We suggest future research to bring insights on this issue.

Finally, Hypothesis 5 also seems to find support in the data: respondents who are 'sometimes' (44\% of the total), 'often' or 'always' (34\%) angry with the economy are more likely to support MMP. This result holds even when controlling for vote choices and party preferences. This has strong implications for referenda in general. The context in New Zealand in the late 80s was of great disengagement with politics and politicians. This was a result of a sudden and strong bulk of free market and liberalization measures that were started out by a Labour government breaking its campaign promises and continued by the National government (Roper and Leitch, 1995). Therefore, it is most likely that 'angry' respondents did not support MMP because of its intrinsic characteristics or because of its potential for specific, long-term policy outcomes. On the contrary, they may have supported MMP because it entailed change, and, furthermore, it was a vote against the "out of touch" (Vowles, 2008) elites of both National and Labour. This has remarkable similarities with recent elections like the Brexit referendum (2016) or the US and Philippines presidential elections of 2016, where it is believed that many voters cast uninformed votes and based their choices on anti-establishment sentiments and a sense of economic disenfranchisement (Hobolt, 2016, Leonard, 2017) ${ }^{32}$

Last, despite not being formally part of any prediction, there are a few other results we would like to discuss. Older people seemed to have preferred a conservative choice (FPTP). Both field and survey results point in the same direction, although these results are not robust to all specifications. Gender results are also mixed, but overall point in the direction that women were on average more supportive of the status quo than men. Survey results show that women were $5-10 \%$ more likely to support FPTP than men. We find the differential effect to be specially pronounced among conservative voters. Pino (2017) uses Chilean elections data and finds that women vote in a more conservative manner than

\footnotetext{
${ }^{32}$ For more on the discussion of the growth (or lack thereof) of anti-establishment voting and policy platforms, see Goodwin and Heath (2016); Hooghe and Dassonneville (2018) and Hanley and Sikk (2016).
} 
men. We also find that Māori overwhelmingly supported MMP. We believe the answer for this lies on the fact that, as discussed above, an increase to the number of Māori seats was linked to a switch in electoral regime. This gave an incentive to Māori who wanted to increase the number of Māori-only districts, beyond any particular considerations on electoral system per se.

Overall, out of the five predictors of electoral system choice we discuss in Section 2. we find that partisan allegiances, social values, and political discontent best explain how people voted in the New Zealand referendum. We also find suggestive evidence that ideological placement matters, whereas we do not find a straightforward relationship between socio-economic status and preferences.

\section{Concluding remarks}

This paper uses a novel strategy in order to ascertain what drives voters' preferences for electoral systems. It is the first one to use results from a binding referendum to that avail (New Zealand, 1993). We find that voters preferences are mostly driven by partisan selfinterest: they support the system that most benefits their favorite party. However, this paper further shows that a purely partisan instrumental model does not suffice to explain voters choices: preferences towards particular democratic processes are also a key factor. In other words, voters place an intrinsic value to processes and mechanisms implied by the different electoral systems, beyond the particular policy outcomes that they may deliver. In particular, we find that people with more progressive values overwhelmingly favor a proportional rule.

Notably, we find that, regardless of socioeconomic status or party allegiances, people who were upset with the economic situation were more likely to vote against the status quo. At the margin, the size of the effect was not negligible in New Zealand: in a close race such as the 1993 referendum, those who seemingly used the referendum to send a signal to party elites may have been critical in securing a victory for the new proportional system. This has notable implications for referenda overall: electors may be tempted to use them to send a signal to politicians, regardless of the particular issue the referendum may be addressing. Hence, results in this paper support the idea that timing of referenda is critical.

Also, this paper uncovers another dimension of the rural-urban duality: the former 
prefer a majoritarian system, whereas the latter prefer a proportional one. Results suggest that this duality is not driven by a preference or distaste for malapportionment. Further research should serve to confirm if there is a preference for accountability in areas that are distant from political power (mostly rural), and a preference for representativity in urban areas.

Other issues also merit further inquiry: we find that religion is strongly correlated with electoral system preferences. We conjecture that this reveals a preference for the status quo among religious groups which are majoritarian and relatively well-off in economic terms. Finally, we find that women are much more supportive of FPTP than men. Whereas similar gender biases have been previously found in the literature, we cannot provide any framework that accounts for such a difference. We hope that further research will shed more light on the issues that have been left partially answered here. pino

Acknowledgments. Financial support from Yale-NUS College is gratefully acknowledged. We would like to thank Kai Ostwald, Julien Labonne, Risa Toha, Rene Saran and the audiences at the National University of Singapore, the University of Montréal, and the Political Economy Workshop at the University of New South Wales for their comments. We would like to especially thank Liang Yun, Yaow Yu Hung and Weiliang Tan for excellent research assistance. All errors are ours.

\section{References}

Aimer, Peter, And Miller, Raymond: Partisanship and principle: Voters and the New Zealand electoral referendum of 1993, European Journal of Political Research, 41, (2002), 795-809.

Aldrich, John, Jason Reifler,ÂU Michael C. Munger: Sophisticated and myopic? Citizen preferences for Electoral College reform, Public Choice, 158, (2014), $541-558$.

Bawn, Kathleen: The logic of institutional preferences: German electoral law as a social choice outcome., American Journal of Political Science, (1993), 965-989.

Benoit, Kenneth: Models of electoral system change, Electoral Studies, 23, (2004), 363-389.

Benoit, Kenneth: Electoral Laws as Political Consequences: Explaining the Origins and Change of Electoral Institutions, Annual Review of Political Science, 10, (2007), 363-390. 
Blais, André, And Indridi H. Indridason: Making Candidates Count: The Logic of Electoral Alliances in Two-Round Legislative Elections, The Journal of Politics, 69 (1), (2007), 193-205.

Blais, André, Jean-François Laslier, François Poinas, Karine Van Der Strateten: Citizens' preferences about voting rules: self-interest, ideology, and sincerity, Public Choice, 164, (2015), 423-442.

Boix, Carles: Setting the Rules of the Game: The Choice of Electoral Systems in Advanced Democracies, American Political Science Review, 93 (3), (1999), 609-624.

Bol, Damien: Electoral reform, values and party self-interest, Party Politics, 22 (1), (2016), 93-104.

Bowler, Shaun, Todd Donovan and Jeffrey A. Karp: Why Politicians Like Electoral Institutions: Self-Interest, Values, or Ideology?, The Journal of Politics, 68 (2), (2006), 434-446.

Carey, John, and Simon Hix: Policy Consequences of Electoral Rules, In "Political Science, Electoral Rules, and Democratic Governance", eds. Mala Htun and G. Bingham Powell. Washington, DC: American Political Science Association, 46-55 (2013).

Colomer, Josep M.: The strategy and history of electoral system choice, In "The Handbook of Electoral System Choice", pp. 3-78. Palgrave Macmillan UK, 2004.

Duverger, Maurice: Les Partis Politiques, 2. éd. rev. et mise à jour. ed. Paris: A. Colin (1951).

Duverger, Maurice: The Political Role of Women, Paris: United Nations Economic and Social Council (1955).

Fournier, Patrick, Henk van der Kolk, R. Kenneth Carty, André Blais, and Jonathan Rose: When Citizens Decide: Lessons from Citizen Assemblies on Electoral Reform, Oxford: Oxford University Press (2011).

Gibson, John, Bonggeun Kim, Steven Stillman, and Geua Boe-Gibson: Time to vote?, Public Choice, 156 (3-4), (2013), 517-536.

Goodwin, Matthew J., And Oliver Heath: The 2016 Referendum, Brexit and the Left Behind: An Aggregate?level Analysis of the Result, The Political Quarterly , 87 (3), (2016), 323-332.

Grofman, Bernard: Perspectives on the Comparative Study of Electoral Systems, Annual Review of Political Science, 19, (2016), 523-540.

Hanley, Seán, And Allan SikK: Economy, corruption or floating voters? Explaining the breakthroughs of anti-establishment reform parties in eastern Europe, Party Politics 22 (4) (2016), 522-533.

Hobolt, SarA B.: The Brexit vote: a divided nation, a divided continent, Journal of European Public Policy, 23 (9), (2016),1259-1277.

Hooghe, Marc, and Ruth Dassonneville: A spiral of distrust: A panel study on the relation between political distrust and protest voting in Belgium, Government and Opposition, 53 (1), (2018),104-130. 
Hooghe, Marc, And Ruth Dassonneville: Explaining the Trump vote: The effect of racist resentment and anti-immigrant sentiments, PS: Political Science \& Politics $\mathbf{5 1}$ (3) (2018), 528-534.

Iversen, Torben, And David Soskice: Electoral Institutions and the Politics of Coalitions: Why Some Democracies Redistribute More than Others?, American Political Science Review, 100, (2006), 165-181.

KAUfFMAn, ERIK: It's NOT the economy, stupid: Brexit as a story of personal values, British Politics and Policy at LSE (2016). Available at http://blogs.lse.ac.uk/ politicsandpolicy/personal-values-brexit-vote/

KATZ, RICHARD S: Why are there so many (or so few) electoral reforms?, in "The Politics of Electoral Systems" ", eds. Gallagher, Michael, and Paul Mitchell. OUP Oxford (2005), $57-76$.

Kedar, Orit, Liran Harsgor, and Raz A. Sheinerman: Are Voters Equal under Proportional Representation?, American Journal of Political Science, 60 (3), (2016), 676-691.

Krosnick, Jon A.: Survey Research, Annual Review of Psychology, 50, (1999), 537-567.

Kselman, Daniel, And Emerson Niou: Protest voting in plurality elections: a theory of voter signaling, Public Choice, 148 (3), (2011), 395-418.

LeOnARD, RoBert: Why Rural America Voted for Trump, The New York Times, January 5, 2017, available at https://www.nytimes.com/2017/01/05/opinion/ why-rural-america-voted-for-trump.html.

Levine, Stephen, And Nigel S. Roberts: The New Zealand electoral referendum of 1992, Electoral Studies, 12 (2), (1993), 158-167.

LiJPhart, Arend : Democracies: Patterns of Majoritarian \& Consensus Government in Twenty-one Countries. New Haven: Yale University Press (1984).

Lizzeri, Alessandro, And Nicola Persico: The Provision of Public Goods under Alternative Electoral Incentives, American Economic Review, 91, (2001), 225-239.

LYNSKEY, DORIAN: 'I thought I?d put in a protest vote': the people who regret voting leave, The Guardian, 25 November 2017. Available at https://www.theguardian. com/politics/2017/nov/25/protest-vote-regret-voting-leave-brexit, last accessed 20 January 2018.

Matland, Richard E. And Studlar, Donley T.: The Contagion of Women Candidates in Single-Member District and Proportional Representation Electoral Systems: Canada and Norway, The Journal of Politics, 58 (3), (1996), 707-733.

MCAllister, IAn: The Australian democrats: Protest vote or portent of realignment?, Politics, 17 (1), (1982), 68-73.

Milesi-Ferretti, Gian-Maria, Roberto Perotti and Massimo Rostagno: Electoral Systems and Public Spending, The Quarterly Journal of Economics, 117 (2), (2002), 609-657. 
Miller, Grant: Women's suffrage, political responsiveness, and child survival in American history, Quarterly Journal of Economics, 123 (3), (2008), 1287-1327.

Morelli, Massimo: Party formation and policy outcomes under different electoral systems, The Review of Economic Studies, 71 (3), (2004), 829-853.

Mulgan, R.: The Elective Dictatorship in New Zealand, in "New Zealand Politics in Perspective", ed. H. Gold; Auckland: Longman Paul (1992), 513-531.

Nagel, JaCK H.: New Zealand: Reform by (Nearly) Immaculate Design, in "The Handbook of Electoral System Choice", ed. J.M. Colomer; New York: Palgrave Macmillan, (2004), 530-543.

Nakaguma, Marcos Yamada: Choosing the form of government: theory and evidence from Brazil, The Economic Journal, 125 (589), (2015), 1986-2023.

NEW Europe: Voting in the Catalan referendum becomes an act of protest, New Europe, 2 October 2017. Available at https://www.neweurope.eu/article/ voting-catalan-referendum-becomes-act-protest/, last accessed 20 January 2018.

New Zealand Parliamentary Library: The Origins of the Māori Seats, Parliamentary Library Research Paper. Available at https://www.parliament.nz/resource/ en-NZ/00PLLawRP03141/e27e432e971eb1f60ea75b00c987a39e4b2e62ce. (2003, updated 2009 version).

Pop-Eleches, Grigore: Throwing out the bums: Protest voting and unorthodox parties after communism, World Politics, 62 (2), (2010), 221-260.

NorRIS, PIPPA: Women's legislative participation in Western Europe, West European Politics, 8 (4), (1985), 90-101.

Norris, PIPPA: Cultural explanations of electoral reform: A policy cycle model, West European Politics 34 (3) (2011), 531-550.

Persson, Torsten, Guido Tabellini and Francesco Trebbi : Electoral Rules and Corruption, Journal of the European Economic Association, 1 (4) (2003), 958-989.

Persson, Torsten, and Guido Tabellini: Constitutional rules and fiscal policy outcomes, American Economic Review, 94 (1), (2004), 25-45.

Persson, Torsten, Gerard Roland, and Guido Tabellini: Electoral Rules and Government Spending in Parliamentary Democracies, Quarterly Journal of Political Science, (2007), 1-34.

Pino, Francisco: Is There Gender Bias Among Voters? Evidence from the Chilean Congressional Elections, ECARES Working Paper 2014-53, available at http://www. franciscopino.com/Site/Research.html.

Quattrone, George A., And Amos Tversky: Contrasting rational and psychological analyses of political choice, American Political Science Review, 82 (3), (1995), 719-736.

Roper, Juliet; And ShIRley Leitch: The electoral reform campaigns in New Zealand: a political communication case study, Australian Journal of Communication, 22 (1), (1995), 123-135. 
Sidanius, Jim, Felicia Pratto and Joshua L. Rabinowitz: Gender, Ethnic Status, and Ideological Asymmetry: A Social Dominance Interpretation, Journal of CrossCultural Psychology, 25 (2), (1994), 194-216.

Trebbi, Francesco, Philippe Aghion, and Alberto Alesina: Electoral rules and minority representation in US cities, The Quarterly Journal of Economics, 123 (1), (2008), 325-357.

VOWles, JACK: Systemic Failure, Coordination, and Contingencies: Understanding Electoral System Change in New Zealand, in "To Keep or To Change First Past The Post?: The Politics of Electoral Reform", ed. André Blais; Oxford: Oxford University Press (2008), 163-182.

Weber, Matthias: Choosing the rules: Preferences over voting systems for assemblies of representatives, Journal of Economic Behavior \& Organization, (2007), http://dx.doi.org/10.1016/j.jebo.2017.01.016.

Wenzel, James P., Shaun Bowler, and David J. Lanoue: Citizen Opinion and Constitutional Choices: The Case of the UK, Political Behavior, 22 (3), (2000), 241265. 


\section{Tables}

Table 1: Referenda and general election results

\begin{tabular}{ccccc}
\hline \hline \multirow{5}{*}{ Panel A: Referenda results } & & \\
Keep & Change & & \\
FPTP & system & Total & Turnout \\
\hline \multirow{2}{*}{1992} & 186,027 & $1,031,257$ & $1,217,284$ & $55.2 \%$ \\
& $15.28 \%$ & $84.72 \%$ & & \\
& FPTP & MMP & & \\
\hline \multirow{2}{*}{1993} & 884,964 & $1,032,919$ & $1,917,833$ & $85.2 \%$ \\
& $46.14 \%$ & $53.86 \%$ & & \\
\hline \hline
\end{tabular}

\section{Panel B: General election results}

\begin{tabular}{lccc} 
Party & \% Votes & Seats & Position referendum \\
\hline National & 35.05 & 50 & Pro FPTP \\
Labour & 34.68 & 45 & Ambiguous \\
Alliance & 18.21 & 2 & Pro MMP \\
NZF & 8.40 & 2 & Pro MMP \\
\hline \hline
\end{tabular}

Official results from the referendum held on September 19, 1992, and general elections and referendum simultaneously held on November 6, 1993. Available at http://www.elections.org.nz.

Table 2: Summary statistics by polling station (General Roll only)

\begin{tabular}{lrrrr} 
& Mean & St. Dev. & Min & Max \\
\hline \hline Panel A: all polling stations we can geo-locate, $N=3,719$ & & \\
\hline \# Referendum votes & 498.8 & 454.7 & 0 & 3094 \\
\% Votes for MMP & $50.14 \%$ & $12.73 \%$ & $2.30 \%$ & $84.0 \%$ \\
\# (REF. - GE) votes & -1.14 & 7.6 & -142 & 106 \\
\# Gral. Election votes & 499.9 & 454.8 & 0 & 3097 \\
\% National & $40.40 \%$ & $17.75 \%$ & $0.72 \%$ & $96.07 \%$ \\
\% Labour & $30.93 \%$ & $16.03 \%$ & $0 \%$ & $88.88 \%$ \\
\% Alliance & $17.31 \%$ & $8.67 \%$ & $0 \%$ & $71.57 \%$
\end{tabular}

Panel B: General roll polling stations (sample used in the remainder), $N=3,244$

\begin{tabular}{lrrrr}
\hline \# Referendum votes & 504.66 & 447.83 & 0 & 3094 \\
\% Votes for MMP & $50.12 \%$ & $13.00 \%$ & $2.30 \%$ & $84.00 \%$ \\
\# (REF. - GE) votes & -0.08 & 3.92 & -24 & 106 \\
\# Gral. Election votes & 504.74 & 447.83 & 0 & 3097 \\
\% National & $40.51 \%$ & $18.40 \%$ & $0.72 \%$ & $96.07 \%$ \\
\% Labour & $30.63 \%$ & $16.40 \%$ & $0 \%$ & $88.88 \%$ \\
\% Alliance & $17.59 \%$ & $8.80 \%$ & $0 \%$ & $71.57 \%$ \\
\hline \hline
\end{tabular}

${ }^{\dagger}$ : Panel A excludes hospital votes, special votes in district before polling day, special votes on polling day, overseas special votes including service personnel votes and ordinary votes in district before polling day. Panel B further excludes polling stations in the Māori roll.

\# $(\mathrm{REF} .-\mathrm{GE})$ votes = Votes in Referendum - Votes in General Election. 
Table 3: Support for MMP at the Polling Station (General Roll only)

\begin{tabular}{|c|c|c|c|c|c|c|}
\hline & $(1)$ & $(2)$ & $(3)$ & $(4)$ & $(5)$ & $(6)$ \\
\hline $\begin{array}{l}\text { Mean MB Area } \\
\text { within AU }\end{array}$ & $\begin{array}{r}-120.3^{* *} \\
(49.52)\end{array}$ & $\begin{array}{r}-98.34^{* *} \\
(42.44)\end{array}$ & $\begin{array}{r}-100.2^{* *} \\
(44.31)\end{array}$ & $\begin{array}{r}-45.69^{* *} \\
(22.51)\end{array}$ & $\begin{array}{r}-94.64^{* *} \\
(40.72)\end{array}$ & $\begin{array}{r}-40.05^{* *} \\
(19.70)\end{array}$ \\
\hline Pop. Density & $\begin{array}{r}1.320^{* * *} \\
(0.403)\end{array}$ & $\begin{array}{r}0.879^{* *} \\
(0.399)\end{array}$ & $\begin{array}{r}0.695^{*} \\
(0.411)\end{array}$ & $\begin{array}{r}-0.247 \\
(0.361)\end{array}$ & $\begin{array}{r}0.525 \\
(0.380)\end{array}$ & $\begin{array}{r}-0.330 \\
(0.341)\end{array}$ \\
\hline$\%$ Women & $\begin{array}{r}0.415^{* *} \\
(0.189)\end{array}$ & $\begin{array}{r}0.269 \\
(0.180)\end{array}$ & $\begin{array}{r}0.453^{* *} \\
(0.185)\end{array}$ & $\begin{array}{r}0.152 \\
(0.127)\end{array}$ & $\begin{array}{r}0.457^{* *} \\
(0.186)\end{array}$ & $\begin{array}{r}0.133 \\
(0.127)\end{array}$ \\
\hline$\%$ Born in NZ & $\begin{array}{r}-0.277 * * * \\
(0.0542)\end{array}$ & $\begin{array}{r}-0.247^{* * *} \\
(0.0532)\end{array}$ & $\begin{array}{r}-0.256^{* * *} \\
(0.0534)\end{array}$ & $\begin{array}{r}-0.156^{* * *} \\
(0.0449)\end{array}$ & $\begin{array}{r}-0.235^{* * *} \\
(0.0539)\end{array}$ & $\begin{array}{r}-0.142^{* * *} \\
(0.0453)\end{array}$ \\
\hline$\%$ Maori & $\begin{array}{r}0.132^{* * *} \\
(0.0483)\end{array}$ & $\begin{array}{r}0.0306 \\
(0.0501)\end{array}$ & $\begin{array}{r}0.0657 \\
(0.0534)\end{array}$ & $\begin{array}{r}0.155^{* * *} \\
(0.0415)\end{array}$ & $\begin{array}{r}0.0941^{*} \\
(0.0534)\end{array}$ & $\begin{array}{r}0.153^{* * *} \\
(0.0409)\end{array}$ \\
\hline$\%>64$ y.o. & $\begin{array}{r}-0.122 \\
(0.0906)\end{array}$ & $\begin{array}{r}-0.297^{* * *} \\
(0.103)\end{array}$ & $\begin{array}{r}-0.248^{* *} \\
(0.109)\end{array}$ & $\begin{array}{r}-0.0646 \\
(0.0796)\end{array}$ & $\begin{array}{r}-0.292^{* * *} \\
(0.107)\end{array}$ & $\begin{array}{r}-0.105 \\
(0.0780)\end{array}$ \\
\hline$\%<25$ y.о. & $\begin{array}{r}-0.154 \\
(0.0977)\end{array}$ & $\begin{array}{r}-0.112 \\
(0.101)\end{array}$ & $\begin{array}{r}-0.109 \\
(0.105)\end{array}$ & $\begin{array}{r}0.0042 \\
(0.0706)\end{array}$ & $\begin{array}{r}-0.145 \\
(0.0988)\end{array}$ & $\begin{array}{r}-0.0004 \\
(0.0709)\end{array}$ \\
\hline \% College degree & $\begin{array}{r}0.390^{* * * *} \\
(0.0635)\end{array}$ & $\begin{array}{r}0.323^{* * * *} \\
(0.0692)\end{array}$ & $\begin{array}{r}0.325^{* * *} \\
(0.0779)\end{array}$ & $\begin{array}{r}0.313^{* * *} \\
(0.0749)\end{array}$ & $\begin{array}{r}0.374^{* * * *} \\
(0.0781)\end{array}$ & $\begin{array}{r}0.342^{* * *} \\
(0.0765)\end{array}$ \\
\hline$\%<$ NZD 20,000 & $\begin{array}{r}-0.0478 \\
(0.0679)\end{array}$ & $\begin{array}{r}-0.297 * * * \\
(0.0911)\end{array}$ & $\begin{array}{r}-0.230^{* *} \\
(0.108)\end{array}$ & $\begin{array}{r}-0.008 \\
(0.087)\end{array}$ & & \\
\hline $\begin{array}{l}\text { Median income } \\
\text { in } \$(000)\end{array}$ & $\begin{array}{r}-0.377^{* * * *} \\
(0.0502)\end{array}$ & $\begin{array}{r}-0.304^{* * *} \\
(0.0615)\end{array}$ & $\begin{array}{r}-0.286^{* * *} \\
(0.0617)\end{array}$ & $\begin{array}{r}-0.151^{* * *} \\
(0.0377)\end{array}$ & $\begin{array}{r}0.640^{* * *} \\
(0.185)\end{array}$ & $\begin{array}{r}0.254^{*} \\
(0.143)\end{array}$ \\
\hline $\begin{array}{l}{\text { (Median income })^{2}}^{\text {in } \$(000)}\end{array}$ & & & & & $\begin{array}{r}-0.007^{* * *} \\
(0.001)\end{array}$ & $\begin{array}{r}-0.003^{* * *} \\
(0.001)\end{array}$ \\
\hline $\begin{array}{l}\% \text { receives some } \\
\text { benefit }\end{array}$ & & $\begin{array}{r}0.482^{* * *} \\
(0.113)\end{array}$ & $\begin{array}{r}0.498^{* * *} \\
(0.135)\end{array}$ & $\begin{array}{r}0.0563 \\
(0.108)\end{array}$ & $\begin{array}{r}0.589^{* * *} \\
(0.128)\end{array}$ & $\begin{array}{r}0.164^{*} \\
(0.0949)\end{array}$ \\
\hline $\begin{array}{l}\text { \% Maori in Maori } \\
\text { Roll (as in 1998) }\end{array}$ & & & $\begin{array}{c}-0.0283 \\
(0.0208)\end{array}$ & $\begin{array}{r}-0.0188 \\
(0.0165)\end{array}$ & $\begin{array}{r}-0.0329 \\
(0.0208)\end{array}$ & $\begin{array}{r}-0.0218 \\
(0.0166)\end{array}$ \\
\hline $\begin{array}{l}\% \text { earns rents } \\
\text { or dividends }\end{array}$ & & & $\begin{array}{r}-0.0865 \\
(0.162)\end{array}$ & $\begin{array}{r}0.364^{* * *} \\
(0.125)\end{array}$ & $\begin{array}{r}-0.172 \\
(0.158)\end{array}$ & $\begin{array}{r}0.321^{* *} \\
(0.126)\end{array}$ \\
\hline$\%$ full employment & & & $\begin{array}{r}0.176 \\
(0.125)\end{array}$ & $\begin{array}{r}0.202^{*} \\
(0.110)\end{array}$ & $\begin{array}{r}0.193^{*} \\
(0.107)\end{array}$ & $\begin{array}{r}0.167^{*} \\
(0.0957)\end{array}$ \\
\hline Party controls & $\mathrm{NO}$ & $\mathrm{NO}$ & $\mathrm{NO}$ & YES & $\mathrm{NO}$ & YES \\
\hline $\mathrm{R}^{2}$ & 0.319 & 0.341 & 0.352 & 0.659 & 0.375 & 0.665 \\
\hline Observations & 3,104 & 3,104 & 2,961 & 2,960 & 2,961 & 2,960 \\
\hline
\end{tabular}

*** Significant at $1 \%$ level; ** at $5 \%$ level; *at $10 \%$ level.

Dependent variable: Percentage of votes for MMP at the Polling Station. All variables refer to Area Unit level data. Population density: (People per $\mathrm{km}^{2}$ )/1,000. Party controls: share of votes for Labour, for National, and for Alliance. Average MB area within AU: average size of meshblocks within the given Area Unit (larger numbers denote rural areas). Standard errors (in parentheses) are clustered at the electoral district level. Regressions are weighted, where weights are given by the number of votes at the polling station: '\#referendum votes at the polling station/\# total referendum votes'. 
Table 4: Support for MMP at the Polling Station, by party support, with sociodemographic controls (General Roll only)

\begin{tabular}{|c|c|c|c|c|}
\hline & (1) & $(2)$ & $\overline{(3)}$ & $(4)$ \\
\hline$\%$ National & $\begin{array}{r}0.0807 \\
(0.0825)\end{array}$ & & & \\
\hline$(\% \text { National })^{2}$ & $\begin{array}{r}-0.0071^{* * *} \\
(0.0008)\end{array}$ & & & \\
\hline$\%$ Labour & & $\begin{array}{r}0.6219^{* * *} \\
(0.1410)\end{array}$ & & \\
\hline$(\% \text { Labour })^{2}$ & & $\begin{array}{r}-0.0073^{* * *} \\
(0.0016)\end{array}$ & & \\
\hline$\%$ Alliance & & & $\begin{array}{r}0.7076^{* * *} \\
(0.1374)\end{array}$ & $\begin{array}{r}0.5023^{* * *} \\
(0.1340)\end{array}$ \\
\hline$(\% \text { Alliance })^{2}$ & & & $\begin{array}{r}-0.0065^{* * *} \\
(0.0020)\end{array}$ & $\begin{array}{c}-0.0037^{*} \\
(0.0020)\end{array}$ \\
\hline$\%$ Nat. - \% Lab. & & & & $\begin{array}{r}0.3304^{* * *} \\
(0.0569)\end{array}$ \\
\hline$(\% \text { Nat. }-\% \text { Lab. })^{2}$ & & & & $\begin{array}{r}-0.0025^{* * *} \\
(0.0003)\end{array}$ \\
\hline Clustered SE & YES & YES & YES & YES \\
\hline Weights & YES & YES & YES & YES \\
\hline Controls & YES & YES & YES & YES \\
\hline $\mathrm{R}^{2}$ & 0.6651 & 0.4023 & 0.4580 & 0.6503 \\
\hline Observations & 2,961 & 2,961 & 2,960 & 2,960 \\
\hline
\end{tabular}

Dependent variable: Percentage of votes for MMP at the Polling Station. \% National - \% Labour = $100+(\%$ National - \% Labour). Controls used (all refer to Area Unit level): mean meshblock area, population density, \% women, $\%$ born in NZ, \% Māori, \% college degree, $\%>64$ y.o., $\%<$ NZD 20,000, median income, \% Māori in Māori Roll, \% earns rents or dividends, \% receives some benefit, \% full employment. Standard errors clustered at the electoral district level. Regressions are weighted, where weights given by number of votes at the polling station: "\#referendum votes at the polling station/\# total referendum votes'.

Table 5: Pairwise matching strategy: one example

Share votes MMP \%National-\%Labour

District Votes for MMP (Polling station level) (Electorate level, 1990)

(i) Polling station: Forrest Hill, Forrest Hill Road, Presbyterian Church Hall

$\begin{array}{llll}\text { Glenfield } & 110 & 44.50 \% & 14.30 \% \\ \text { North Shore } & 437 & 56.50 \% & 28.30 \%\end{array}$

(ii) Polling station: Te Peka Street, K.C.E.P.B. Depot

\begin{tabular}{llll} 
King Country & 39 & $36.10 \%$ & $45.08 \%$ \\
Tongariro & 89 & $51.10 \%$ & $6.21 \%$ \\
\hline
\end{tabular}

(iii) Polling station: Petane Road, No. 58, King George Hall

$\begin{array}{llll}\text { Waikaremoana } & 185 & 54.50 \% & 36.76 \% \\ \text { Napier } & 434 & 61.30 \% & -6.98 \%\end{array}$


Table 6: Support for MMP at the Polling Station, pairwise matching

\begin{tabular}{|c|c|c|c|c|c|}
\hline & $(1)$ & $(2)$ & $(3)$ & $(4)$ & $(5)$ \\
\hline$\%$ National & $\begin{array}{r}-0.260^{* * *} \\
(0.0663)\end{array}$ & & & & \\
\hline$\%$ Labour & & $\begin{array}{r}0.218^{* *} \\
(0.0958))\end{array}$ & & & \\
\hline$\%$ New Labour & & & $\begin{array}{r}0.399^{* * *} \\
(0.109)\end{array}$ & $\begin{array}{r}0.183 \\
(0.180)\end{array}$ & $\begin{array}{r}-0.0515 \\
(0.176)\end{array}$ \\
\hline$\%$ Nat. - \% Lab. & & & & $\begin{array}{c}-0.121^{* *} \\
(0.0449)\end{array}$ & $\begin{array}{r}-0.134^{* * *} \\
(0.0463)\end{array}$ \\
\hline Electorate Area & & & & & $\begin{array}{r}-0.152^{* *} \\
(0.0608)\end{array}$ \\
\hline Meshblock Area & & & & & $\begin{array}{r}-1.109^{* * *} \\
(0.386)\end{array}$ \\
\hline Clustered SE & YES & YES & YES & YES & YES \\
\hline Polling Station FE & YES & YES & YES & YES & $\mathrm{NO}$ \\
\hline $\mathrm{R}^{2}$ & 0.830 & 0.820 & 0.814 & 0.828 & 0.298 \\
\hline Observations & 282 & 282 & 282 & 282 & 282 \\
\hline
\end{tabular}

*** Significant at $1 \%$ level; ** at $5 \%$ level; *at $10 \%$ level.

Dependent variable: Percentage of votes for MMP at the Polling station. All vote shares refer to the general election in 1990. '\% Nat. - \% Lab.': difference in vote shares between both parties in the electorate polling station $i$ of electorate $e$. Electorate Area: Meshblock Area: \# Polling stations in electorate. log (area meshblock where polling station is located at). Standard errors clustered at the electorate level (75 clusters). Fixed effects: polling station. 
Table 7: Support for MMP, New Zealand Election Study, 1993 survey

\begin{tabular}{|c|c|c|c|}
\hline & $(1)$ & $(2)$ & $(3)$ \\
\hline $\begin{array}{l}\text { Vote } 1990=\text { Labour } \\
\text { (base: vote } 1990=\text { National) }\end{array}$ & $\begin{array}{r}0.2252^{* * *} \\
(0.0315)\end{array}$ & $\begin{array}{r}0.1769 * * * \\
(0.0293)\end{array}$ & $\begin{array}{r}0.0827^{* *} \\
(0.0325)\end{array}$ \\
\hline Vote $1990=$ Other & $\begin{array}{r}0.3089 * * * \\
(0.0372)\end{array}$ & $\begin{array}{r}0.2002^{* * * *} \\
(0.0358)\end{array}$ & $\begin{array}{r}0.1201^{* * *} \\
(0.0367)\end{array}$ \\
\hline $\begin{array}{l}\text { Vote } 1990=\text { None or } \\
\text { ineligible }\end{array}$ & $\begin{array}{r}0.3592^{* * *} \\
(0.0656)\end{array}$ & $\begin{array}{r}0.2023^{* * *} \\
(0.0602)\end{array}$ & $\begin{array}{r}0.1522^{* *} \\
(0.0594)\end{array}$ \\
\hline Age & $\begin{array}{r}0.0126^{* *} \\
(0.0049)\end{array}$ & $\begin{array}{r}0.0090^{* *} \\
(0.0045)\end{array}$ & $\begin{array}{r}0.0069 \\
(0.0045)\end{array}$ \\
\hline $\mathrm{Age}^{2} / 100$ & $\begin{array}{r}-0.0109 * * \\
(0.0052)\end{array}$ & $\begin{array}{r}-0.0061 \\
(0.0048)\end{array}$ & $\begin{array}{r}-0.0046 \\
(0.0047)\end{array}$ \\
\hline Female & $\begin{array}{r}-0.0706^{* * *} \\
(0.0254)\end{array}$ & $\begin{array}{r}-0.0573^{* *} \\
(0.0230)\end{array}$ & $\begin{array}{r}-0.0493^{* *} \\
(0.0221)\end{array}$ \\
\hline Income & $\begin{array}{r}-0.0010 \\
(0.0007)\end{array}$ & $\begin{array}{r}-0.0008 \\
(0.0007)\end{array}$ & $\begin{array}{r}-0.0005 \\
(0.0006)\end{array}$ \\
\hline $\begin{array}{l}\text { Māori } \\
\text { (base: white) }\end{array}$ & $\begin{array}{r}0.1494^{* *} \\
(0.0620)\end{array}$ & $\begin{array}{r}0.1309 * * \\
(0.0620)\end{array}$ & $\begin{array}{r}0.1101 \\
(0.0668)\end{array}$ \\
\hline Immigrant & $\begin{array}{r}0.0640^{* *} \\
(0.0317)\end{array}$ & $\begin{array}{r}0.0273 \\
(0.0307)\end{array}$ & $\begin{array}{r}0.0307 \\
(0.0284)\end{array}$ \\
\hline $\begin{array}{l}\text { School } \\
\text { (base: no qual.) }\end{array}$ & $\begin{array}{r}0.0823^{* *} \\
(0.0349)\end{array}$ & $\begin{array}{r}0.0641^{* *} \\
(0.0323)\end{array}$ & $\begin{array}{r}0.0694^{* *} \\
(0.0316)\end{array}$ \\
\hline Non-univ. degree & $\begin{array}{r}0.1506^{* * *} \\
(0.0366)\end{array}$ & $\begin{array}{r}0.1084^{* * * *} \\
(0.0333)\end{array}$ & $\begin{array}{r}0.1119^{* * *} \\
(0.0326)\end{array}$ \\
\hline Univ. Degree & $\begin{array}{r}0.1524^{* * *} \\
(0.0452)\end{array}$ & $\begin{array}{r}0.1163^{* * * *} \\
(0.0410)\end{array}$ & $\begin{array}{r}0.1302^{* * *} \\
(0.0394)\end{array}$ \\
\hline $\begin{array}{l}\text { Employed } \\
\text { (base: retired) }\end{array}$ & $\begin{array}{r}-0.0762 \\
(0.0508)\end{array}$ & $\begin{array}{r}-0.0432 \\
(0.0491)\end{array}$ & $\begin{array}{r}-0.0393 \\
(0.0444)\end{array}$ \\
\hline $\begin{array}{l}\text { Catholic } \\
\text { (base: not religious) }\end{array}$ & $\begin{array}{r}0.0103 \\
(0.0409)\end{array}$ & $\begin{array}{r}0.0389 \\
(0.0362)\end{array}$ & $\begin{array}{r}0.0346 \\
(0.0365)\end{array}$ \\
\hline Protestant & $\begin{array}{r}-0.0821 * * * \\
(0.0272)\end{array}$ & $\begin{array}{r}-0.0371 \\
(0.0246)\end{array}$ & $\begin{array}{c}-0.0417^{*} \\
(0.0239)\end{array}$ \\
\hline Left-Right & $\begin{array}{r}-0.0552^{* * *} \\
(0.0121)\end{array}$ & $\begin{array}{r}-0.0275^{* *} \\
(0.0115)\end{array}$ & $\begin{array}{r}0.0029 \\
(0.0110)\end{array}$ \\
\hline Pol. Know. & $\begin{array}{r}-0.0124 \\
(0.0304)\end{array}$ & $\begin{array}{r}-0.0284 \\
(0.0273)\end{array}$ & $\begin{array}{r}-0.0071 \\
(0.0269)\end{array}$ \\
\hline Political participation & $\begin{array}{r}0.0462^{* *} \\
(0.0223)\end{array}$ & $\begin{array}{c}0.0364^{*} \\
(0.0206)\end{array}$ & $\begin{array}{r}0.0443^{* *} \\
(0.0206)\end{array}$ \\
\hline $\begin{array}{l}\text { Sometimes angry } \\
\text { (base: never/rarely) }\end{array}$ & $\begin{array}{r}0.1969 * * * \\
(0.0312)\end{array}$ & $\begin{array}{r}0.1286^{* * * *} \\
(0.0283)\end{array}$ & $\begin{array}{r}0.0729 * * \\
(0.0293)\end{array}$ \\
\hline Often/always angry & $\begin{array}{r}0.3208^{* * *} \\
(0.0390)\end{array}$ & $\begin{array}{r}0.2110^{* * * *} \\
(0.0360)\end{array}$ & $\begin{array}{r}0.0640 \\
(0.0399)\end{array}$ \\
\hline $\begin{array}{l}\text { Favors conservative } \\
\text { policies }\end{array}$ & $\begin{array}{r}-0.0215^{* * *} \\
(0.0051)\end{array}$ & $\begin{array}{r}-0.0083 \\
(0.0051)\end{array}$ & $\begin{array}{r}-0.0098^{*} \\
(0.0050)\end{array}$ \\
\hline $\begin{array}{l}\text { Support principles } \\
\text { of MMP }\end{array}$ & & $\begin{array}{r}0.1244^{* * * *} \\
(0.0077)\end{array}$ & $\begin{array}{r}0.1013^{* * *} \\
(0.0081)\end{array}$ \\
\hline Support National & & & $\begin{array}{r}-0.0840^{* * *} \\
(0.0130)\end{array}$ \\
\hline Support Labour & & & $\begin{array}{r}0.0205^{*} \\
(0.0117)\end{array}$ \\
\hline Support Alliance & & & $\begin{array}{r}0.0606^{* * *} \\
(0.0118)\end{array}$ \\
\hline $\mathrm{R}^{2}$ & 0.2984 & 0.4179 & 0.4565 \\
\hline Observations & 1,296 & 1,286 & 1,286 \\
\hline
\end{tabular}

Dependent variable: Vote for MMP in the referendum (dummy). Standard errors clustered at the electorate level.

Pol. know.: knows the name of the local MP. Political participation: \# general elections voted in since 1987. Angry economy: "I feel angry about the economy" ( $1=$ never; $2=$ seldom; $3=$ sometimes; $4=$ often; $5=$ always). Support National/Labour/Alliance: $1=$ Strongly oppose; $5=$ Strongly support.

Favors conservative policies $\in[-6,6]=$ Pro-reducing \# immigrants $(\in[-2,2])+$ Against employing homosexuals $(\in[-2,2])$ + Favors death penalty $(\in[-2,2])$, where $-2=$ Strongly disagree; $2=$ Strongly agree.

Support principles of MMP $\in[-4,4]$ : This variable is constructed using two questions from the NZES 1993 survey: (i) F1d: "An election should give each party a share of the MPs equal to its share of the vote", Strongly Agree $(+2)$ Agree $(+1)$ Disagree (-1) Strongly disagree (-2); and (ii) F1c: "An election should ensure that one party can form a government", Strongly Agree (-2) Agree (-1) Disagree (+1) Strongly disagree (+2).

Omitted categories: 'Don't know/No Answer' income; 'other' ethnic group; 'other/student' employment status; 'other' religion; 'Don't know/No Answer' self Left-Right position; 'Don't know/No Answer' angry with economy. 
Table 8: Support for MMP, New Zealand Election Study, 1993 survey

\begin{tabular}{lrrrr} 
& $(1)$ & $(2)$ & $(3)$ & $(4)^{\ddagger}$ \\
\cline { 2 - 5 } Left-Right & -0.002 & -0.002 & -0.008 & -0.008 \\
& -0.011 & -0.011 & -0.013 & -0.013 \\
Support National & $-0.081^{* * *}$ & $-0.043^{* * *}$ & $-0.079^{* * *}$ & $-0.046^{* * *}$ \\
& -0.013 & -0.015 & -0.015 & -0.017 \\
Support Labour & $0.022^{*}$ & $0.032^{* *}$ & 0.017 & $0.027^{*}$ \\
& -0.012 & -0.015 & -0.012 & -0.014 \\
Support Alliance & $0.048^{* * *}$ & $0.038^{* * *}$ & $0.045^{* * *}$ & $0.035^{* *}$ \\
& -0.013 & -0.014 & -0.013 & -0.014 \\
Support NZF & $0.034^{* * *}$ & $0.025^{*}$ & 0.023 & 0.015 \\
& -0.013 & -0.014 & -0.014 & -0.016 \\
Support Christian Heritage & & & 0.016 & 0.014 \\
& & & -0.013 & -0.013 \\
1993 Vote: None/Other & & $0.132^{*}$ & & 0.081 \\
base: vote for National) & & -0.077 & & -0.085 \\
1993 Vote: Labour & & $0.131^{* * *}$ & & $0.105^{* *}$ \\
& & -0.045 & & -0.049 \\
1993 Vote: Alliance & & $0.223^{* * *}$ & & $0.208^{* * *}$ \\
& & -0.041 & & -0.048 \\
1993 Vote: New Zealand First & & $0.209^{* * *}$ & & $0.186^{* * *}$ \\
1993 Vote: Christian Heritage & & -0.051 & & -0.059 \\
& & $0.170^{*}$ & & 0.089 \\
$\mathrm{R}^{2}$ & & -0.088 & & -0.089 \\
Observations & 0.461 & 0.475 & 0.475 & 0.487 \\
\hline \hline
\end{tabular}

*** Significant at $1 \%$ level; ${ }^{* *}$ at $5 \%$ level; ${ }^{*}$ at $10 \%$ level.

Dependent variable: Vote for MMP in the referendum (dummy). Standard errors clustered at the electorate level. All regressions include the same controls as Column (3) of Table 7 


\section{Figures}

Figure 1: New Zealand 1993 electorates.

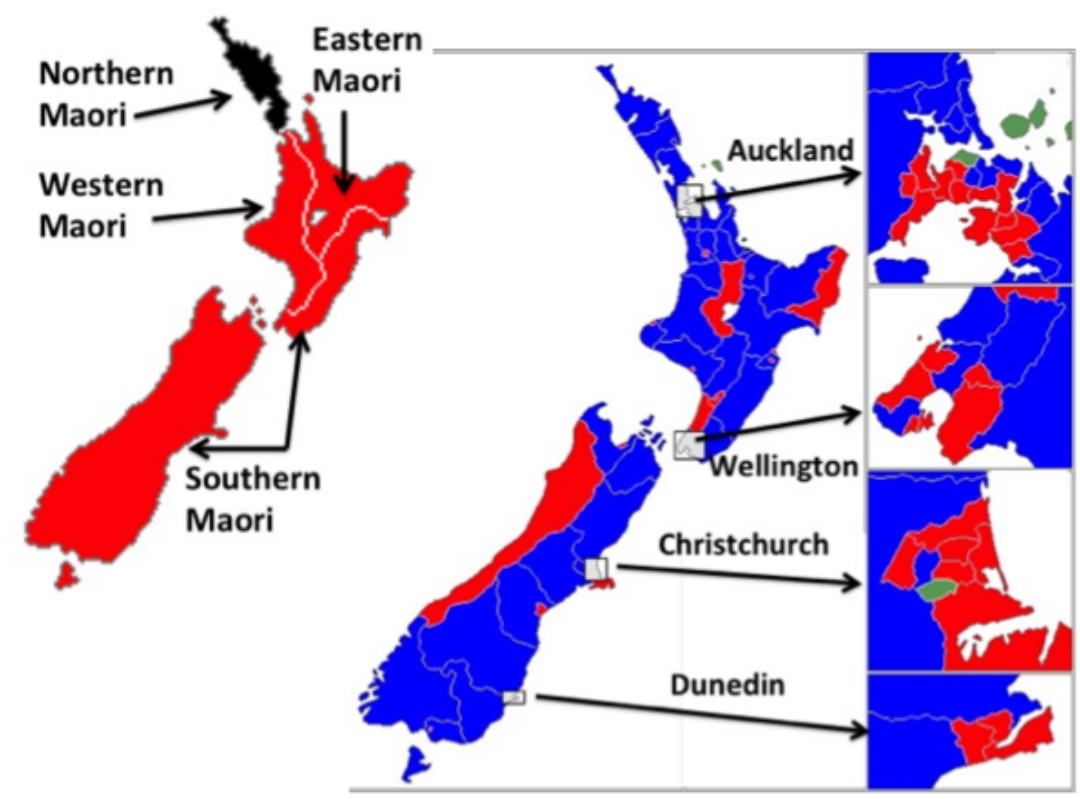

Left figure: Māori roll districts. Right figure: General roll districts. The colors refer to the general election results: $\operatorname{Red}=$ Labour victory. Blue $=$ National victory. Black $=$ New Zealand First victory. Green $=$ Alliance victory.

Figure 2: Distribution of support for MMP

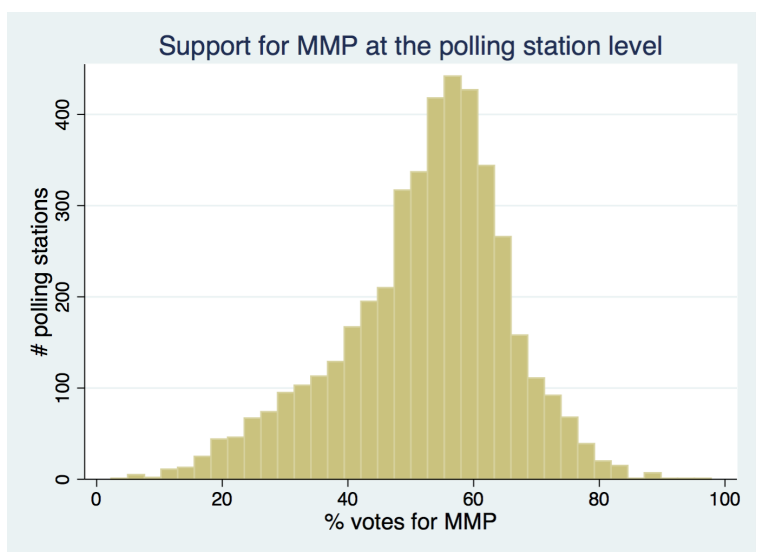

(a) Across all polling stations

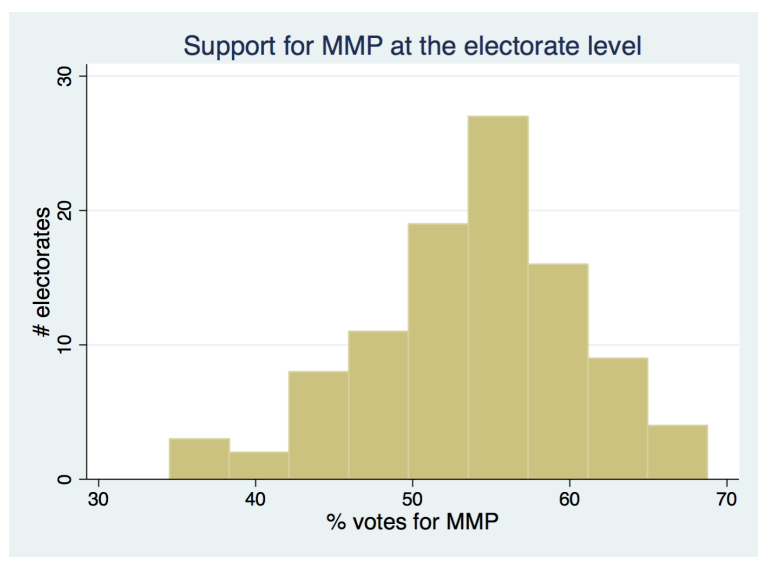

(b) Across all electorates 
Figure 3: Geographical distribution of support for MMP and the three biggest parties

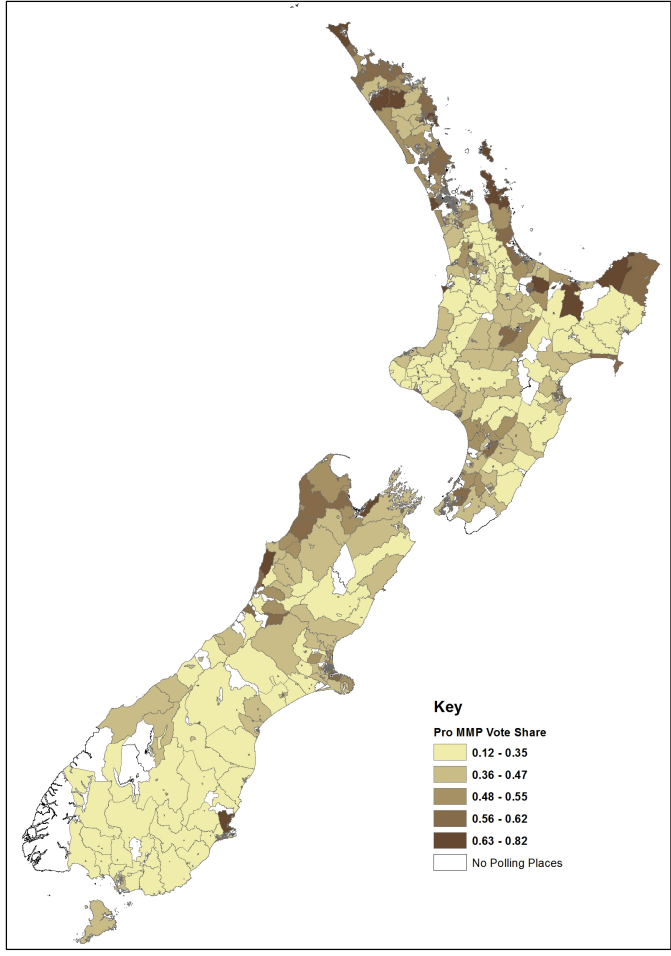

(a) Support for MMP

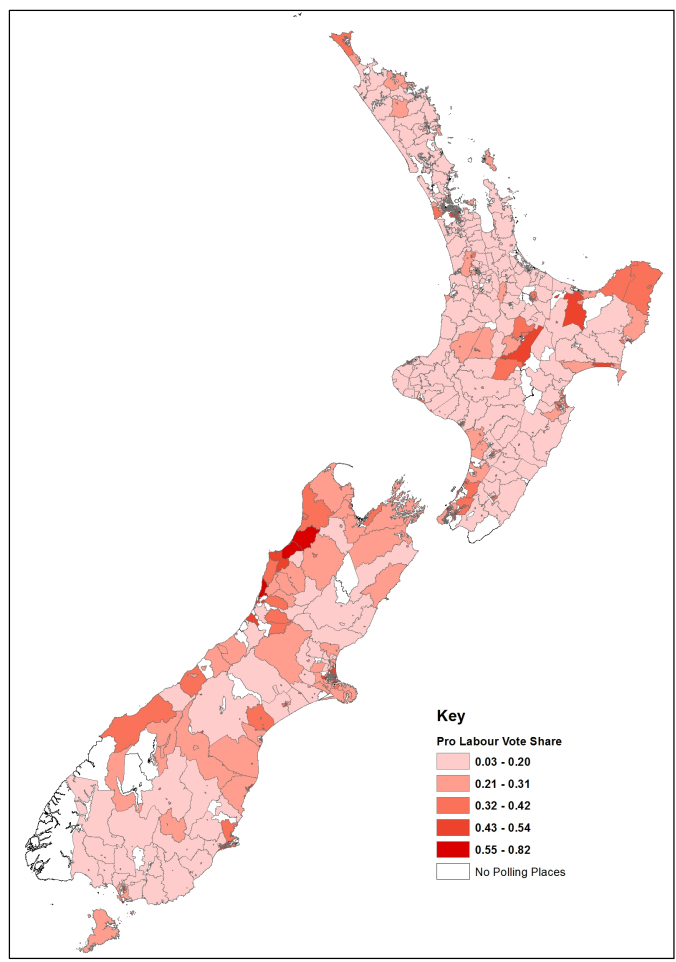

(c) Support for Labour

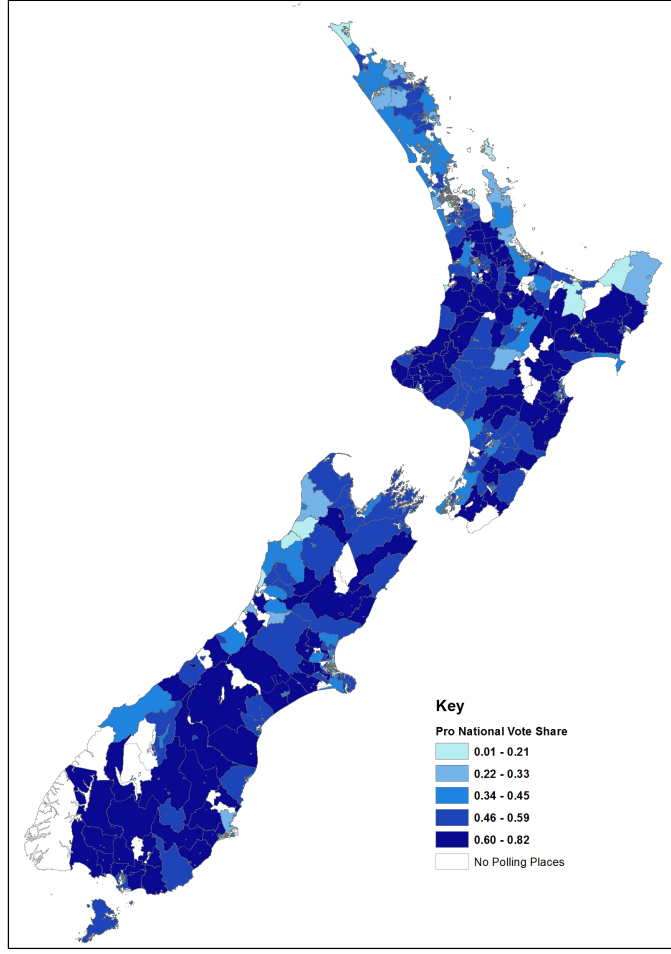

(b) Support for National

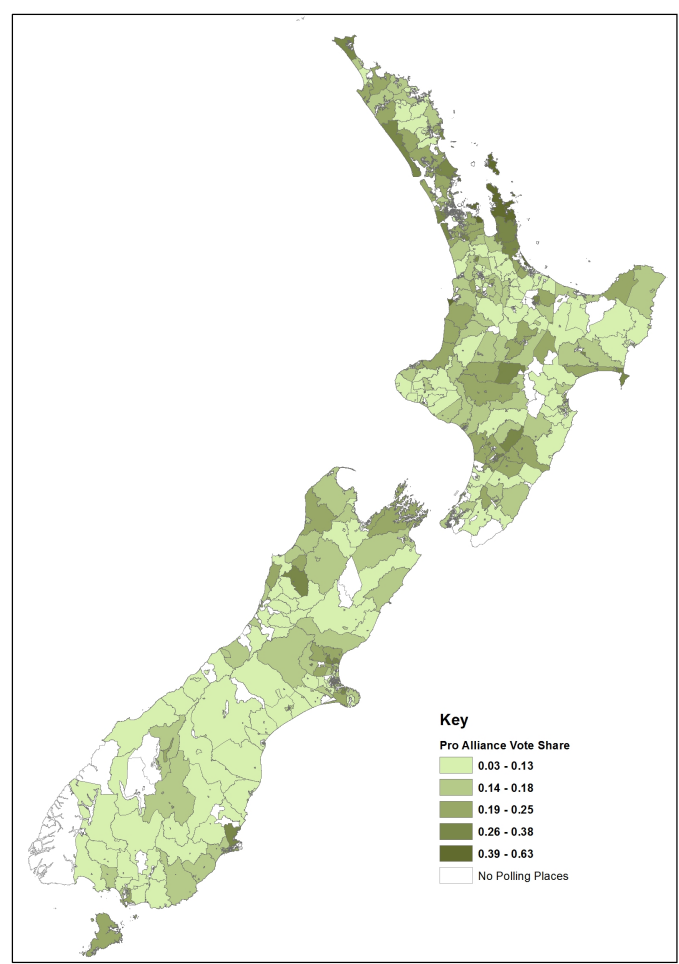

(d) Support for Alliance

Darker tones denote more support. Natural breaks used: Figure 3a $(0-12 \% ; 12-35 \% ; 36-47 \%$; 48-55\%; $56-62 \% ; 62-82 \%)$. Figure 3b (1-21\%; 22-33\%; 34-45\%; 46-59\%; 60-82\%). Figure 3c (3-20\%; $21-31 \%$; $32-42 \% ; 43-54 \% ; 55-82 \%)$. Figure 3d (3-13\%; 14-18\%; 19-25\%; 26-38\%; 39-63\%) 
Figure 4: Support for MMP by party support
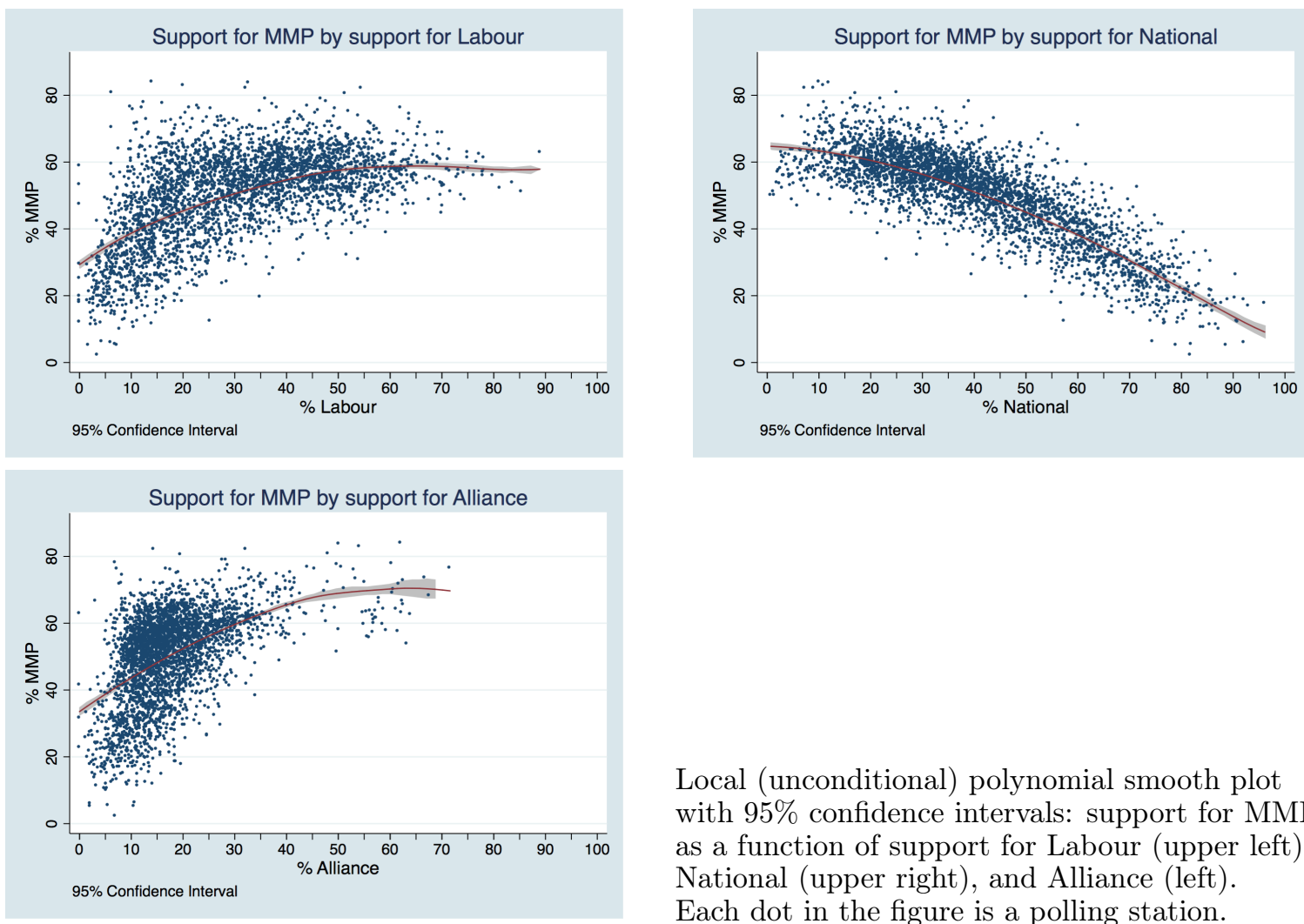

Local (unconditional) polynomial smooth plot with $95 \%$ confidence intervals: support for MMP as a function of support for Labour (upper left), National (upper right), and Alliance (left). Each dot in the figure is a polling station. 
Figure 5: Predicted support for MMP, by party support

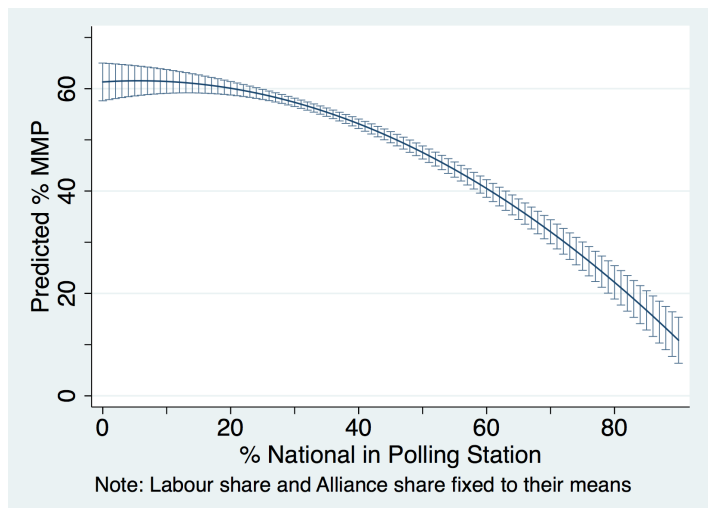

(a) Conditional on the share of votes for National at the polling station - specification (1) in Table 4

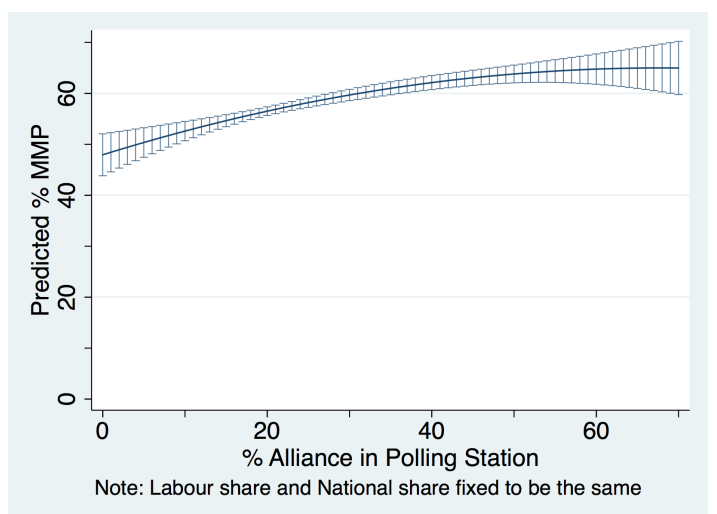

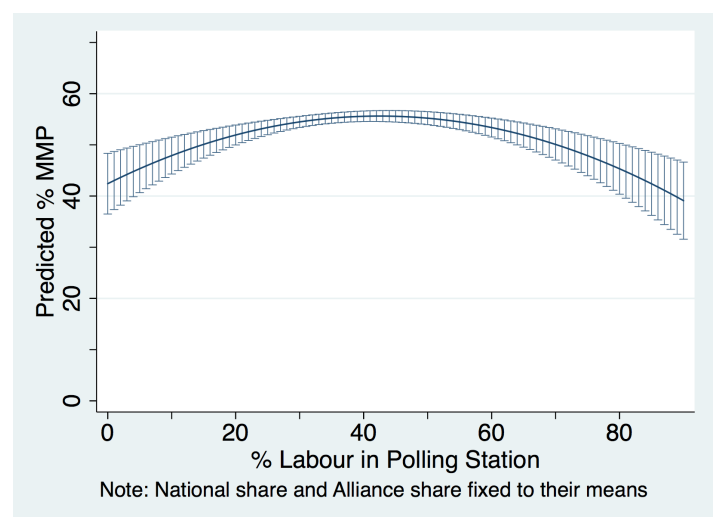

(b) Conditional on the share of votes for Labour at the polling station - specification (2) in Table 4 (c) Conditional on the share of votes for Alliance at the polling station, fixing the shares of National and Labour to be the same. Note: the maximum share for Alliance at any polling station is $72 \%$. Specification (4) in Table 4

Predicted shares for MMP taken from Table 4 (95\% confidence intervals plotted). See expression (1) for the regression specification.

Figure 6: Predicted support for MMP by party support, using matched polling stations only
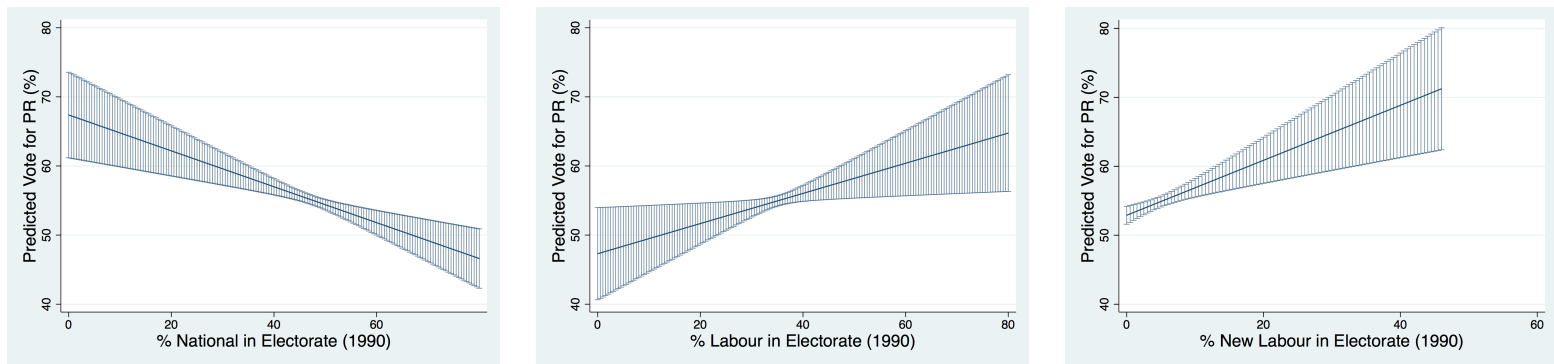

Predicted shares for MMP taken from Table 6 (95\% confidence intervals plotted). See expression (2) for the regression specification.

Figure 7: Predicted support for MMP by party support, survey data
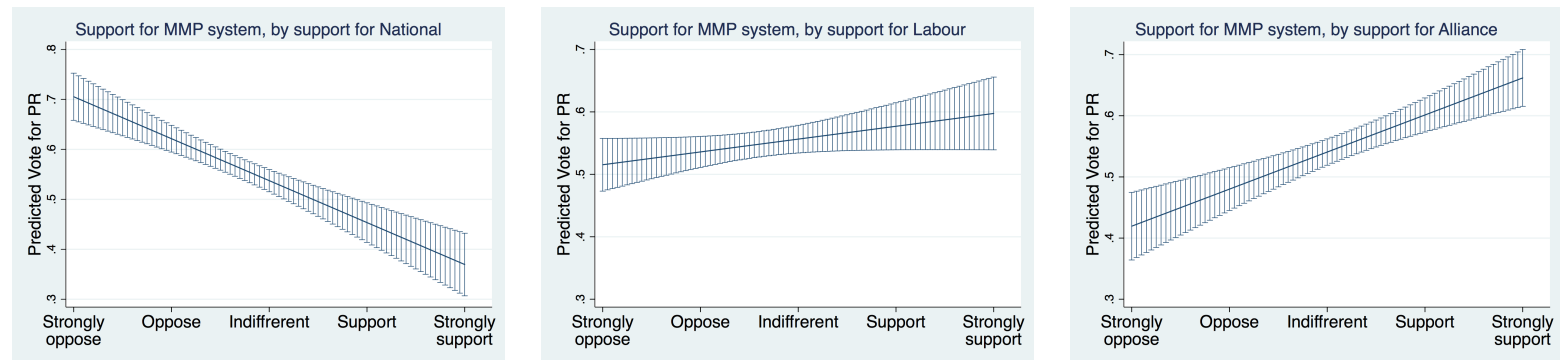

Predicted probability of voting for MMP taken from (3) in Table 7 (95\% confidence intervals plotted). See expression (3) for the regression specification. 
Figure 8: Predicted support for MMP, by individual beliefs, values, and socioeconomic characteristics (95\% confidence intervals plotted). All figures (unless otherwise stated) are derived from specification (3) in Table 7. See expression (1) for the regression specification.

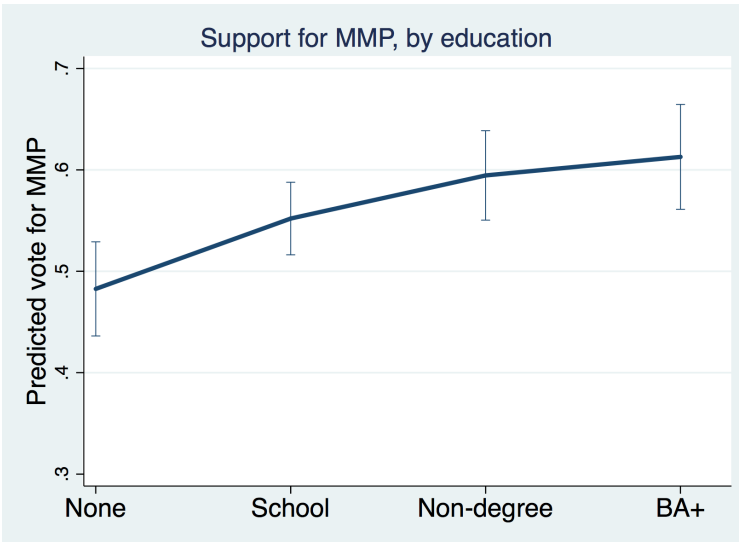

(a) By level of education

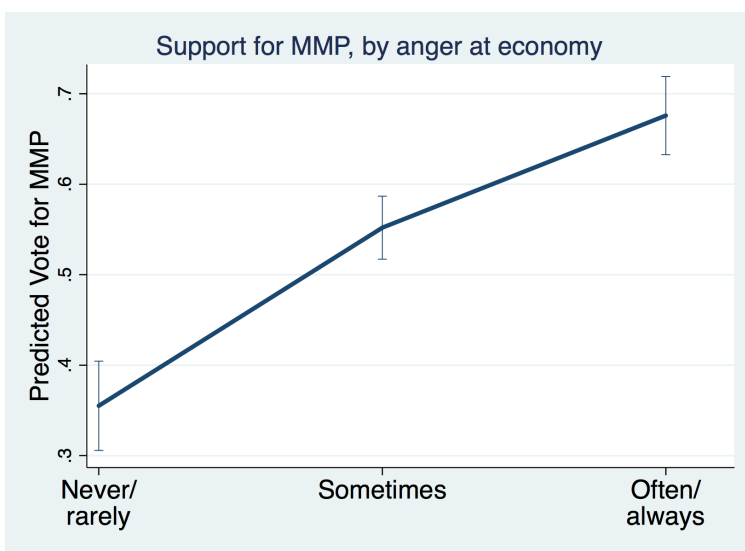

(c) By anger at the economy (from specification (1) in Table 7

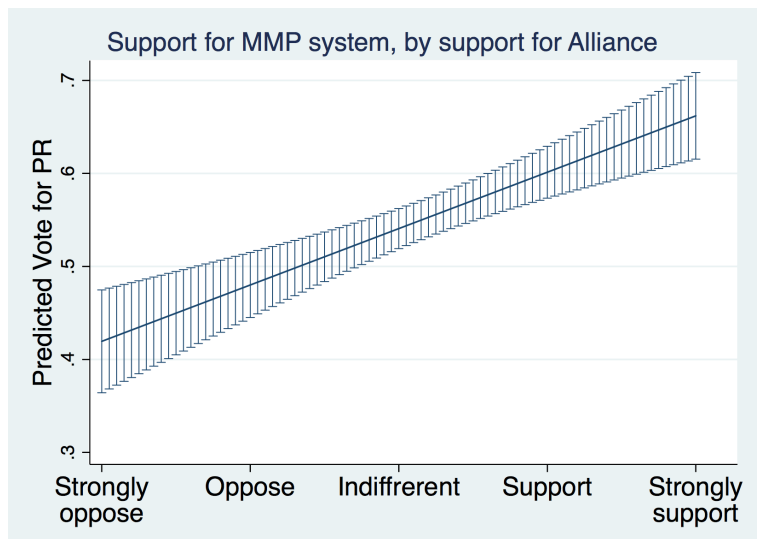

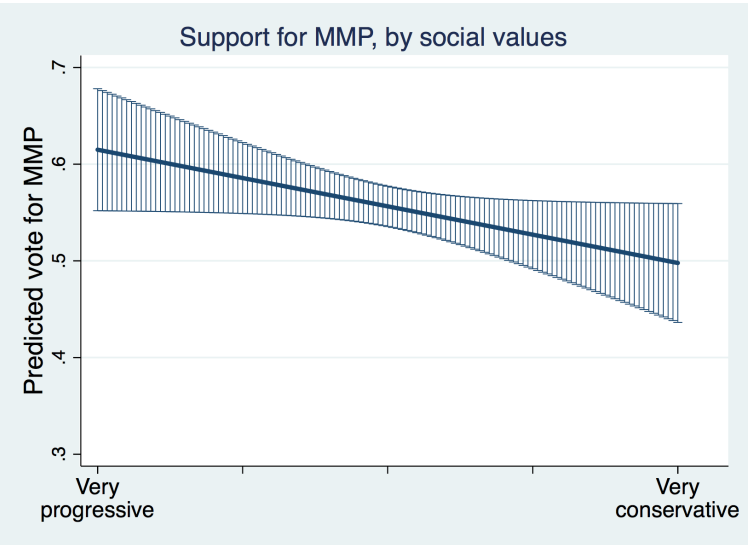

(b) By social values

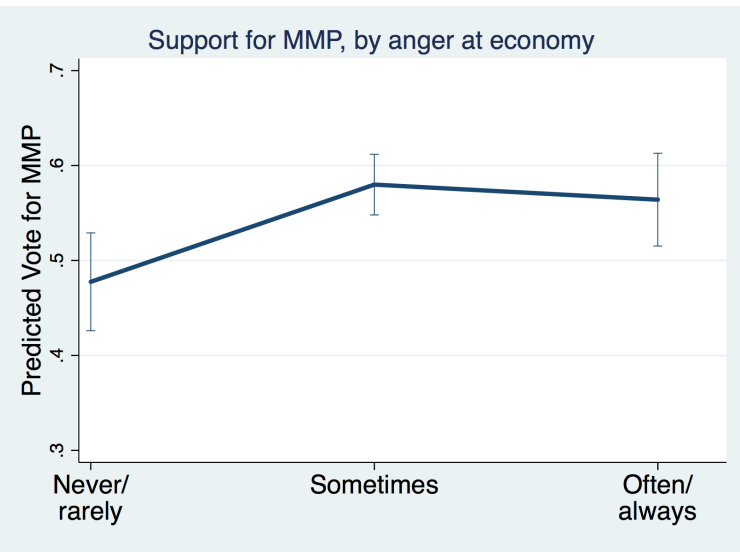

(c) By anger at the economy

(e) By support to Alliance (same as in Figure 7 included here to facilitate comparison of magnitude to other explanatory variables) 